\title{
11 Opportunities for Water Harvesting and Supplemental Irrigation for Improving Rainfed Agriculture in Semi-arid Areas
}

\author{
P. Pathak, K.L. Sahrawat, ${ }^{* *}$ S.P. Wani, ${ }^{* * *}$ R.C. Sachan**** \\ and R. Sudi***** \\ International Crops Research Institute for the Semi-Arid Tropics (ICRISAT), \\ Patancheru 502 324, Andhra Pradesh, India; \\ emails:*p.pathak@cgiar.org; ${ }^{* *}$ k.sahrawat@cgiar.org; ${ }^{* * *}$ s.wani@cgiar.org; \\ ****r.sachan@cgiar.org; *****s.r.rao@cgiar.org
}

\section{Introduction}

Most of the food in the world is produced under rainfed agriculture, which plays a key role in poverty reduction (Rockström et al., 2007). The majority of poor people in the world are dependent on rainfed agriculture for food and income and thus livelihood security (FAO, 2002). The importance of rainfed agriculture varies regionally, but most food for poor communities in the developing countries is produced under rainfed agriculture (Rockström et al., 2007). In rainfed agriculture, water is the key constraint for improving agricultural productivity owing to the extreme variability of rainfall, long dry seasons, recurrent droughts, and floods and dry spells in the same season. In spite of being important for world food security, the investments in rainfed agriculture, particularly in water management, have been neglected since the late 1950s. However, the investments in rainfed agriculture have shown large pay-offs in yield improvements and poverty alleviation through income generation and environmental sustainability (SIWI, 2000; Wani et al., 2003b). This is the conclusion of the Comprehensive Assessment of Water Management in Agriculture, given that rainfed agriculture, particularly in the world's most water-challenged regions, is a risky business, with current yields generally less than half of those in the irrigated systems, where risks due to water shortages are much lower.

The semi-arid tropics (SAT), where rainfall exceeds potential evapotranspiration for 2-4.5 months per year (Troll, 1965), has predominantly rainfed agriculture. Rainfall in the SAT generally occurs in short torrential downpours. A large portion of this water is lost as run-off, eroding significant quantities of precious top soil. The current rainwater use efficiency for crop production is low, ranging from 30 to $55 \%$; thus annually a large percentage of seasonal rainfall is lost as surface run-off, evaporation or deep drainage. Groundwater levels are depleting in the SAT regions, and most rural rainfed areas are facing general water scarcity and drinking water shortages in the summer months. Though the problem of water shortages and land degradation has also been in existence in the past, the pace of natural resource degradation has greatly increased in recent times due to the burgeoning population and the increased exploitation of natural resources. An insight into the rainfed SAT regions shows a grim picture of water scarcity, 
fragile ecosystems, drought and land degradation due to soil erosion by wind and water, low rainwater use efficiency, high population pressure, poverty, low investments in water use efficiency measures and inappropriate policies (Wani et al., 2003a; Rockström et al., 2007).

Research results from the various institutions/organizations have clearly shown that there is vast potential for improving agricultural productivity in the rainfed SAT. However, the adoption of improved technologies by the resource-poor farmers in the rainfed SAT is limited, primarily due to risk associated with drought. The key challenge is to reduce watershortage-related risks posed by high rainfall variability rather than coping with an absolute lack of water. There is generally enough rainfall to double and often even quadruple the crop yields in rainfed farming systems, even in the water-constrained regions. But the distribution of rainfall leads to dry spells, and much of the rainwater is lost. Apart from water, upgrading rainfed agriculture requires investments in soil, crop and farm management. However, to achieve these, the rainfall-related risks need to be reduced.

Run-off water harvesting and the use of water for supplemental irrigation is an age-old practice. The critical importance of supplemental irrigation lies in its capacity to bridge dry spells and thereby reduce the risks in rainfed agriculture. Since the late 1960s, considerable research on water harvesting and supplemental irrigation has been conducted across the world, but the literature remains scattered. This chapter discusses the research results and experiences gained in run-off harvesting and supplemental irrigation in the SAT of India and Africa. The current state-of-the-art knowledge about the following seven key aspects of water harvesting and supplemental irrigation is covered in detail:

- Traditional tank irrigation in SAT India.

- Assessment of adequate water availability in tank at critical crop growth stages.

- Optimum tank size and other design parameters.

- Efficient application of supplemental irrigation water.

- Crop responses to supplemental irrigation.
- Economic evaluation of run-off storage structures and supplemental irrigation.

- Watershed-based water harvesting, groundwater recharging and efficient water utilization.

\section{Traditional Tank Irrigation System in SAT India}

Water harvesting is an ancient art practised in many parts of northern America, the Middle East, North Africa, China and India. Different indigenous techniques and systems were developed in different parts of the world, and they are still referred to in the literature by their traditional names. Among these are haffir and teru in Sudan, gessour in Tunisia, khadin or tank in India, lacs calinaires in Algeria, caag and gawans in Somalia, sayl in Yemen, khuls in Pakistan and boqueras in Spain. Ancient water-harvesting systems are characterized by flexibility and endurance. Flexibility is demonstrated by their easy integration with other resource-use systems as well as their widespread adoption by diverse cultural groups in various parts of the world. Endurance is shown by their antiquity and their capacity to survive situations of abrupt changes in the social order. In India, tank irrigation is one such ancient practice which is still in use in several parts of the country.

In India, tank irrigation is a long-established practice and many tanks are centuries old. Here the 'tank' is a small water reservoir behind an earthen dam or a pond excavated out of a field to catch and hold run-off. Tanks are constructed and maintained by irrigation departments ( $>40$ ha command area) and panchayat unions (village government). Farmers are responsible for water distribution and management below the outlet. The use of tank-based systems in SAT India is quite widespread. However, the states of Andhra Pradesh and Tamil Nadu contain about $60 \%$ of the tank-irrigated area in SAT India. In these states the proportion of tank-irrigated area as a percentage of the total irrigated area has been declining at the rate of $0.3 \%$ per year since the late 1970 s, largely because of poor management and maintenance. The average tank command area in various districts ranged from 10.3 to 49.1 ha, 
usually used for paddy rice (Sharma and Helweg, 1982; von Oppen and Subba Rao, 1987).

In a study of 45 tanks grouped according to size, in the Anantapur district in Andhra Pradesh, von Oppen and Subba Rao (1987) found that for small tanks (below 400 ha command area) the ratio of command area to tank bed area was 0.9 while for large tanks (above 400 ha command area) it was 1.5. The average bund length per hectare of command area was $5.1 \mathrm{~m}$ in large tanks and $21.9 \mathrm{~m}$ in small tanks, with an average of $10.6 \mathrm{~m}$ for all tanks. The storage capacity (in terms of depth) of water per unit of command area averaged $1.4 \mathrm{~m}$. In the traditional small reservoir three to five times more than the water requirements was supplied to the rice crop. Very low water use efficiency, which ranged between 15 and $30 \mathrm{~kg} / \mathrm{cm} / \mathrm{ha}$ of water, was found. The water use efficiency of the overall system was still lower, in the range of 11 to $21 \mathrm{~kg} / \mathrm{cm} / \mathrm{ha}$ of water, owing to heavy seepage and evaporation losses. The study of von Oppen and Subba Rao (1987) indicated that the traditional tank irrigation system is highly subsidized by the local government. It is estimated that about $97 \%$ of the cost of tank irrigation is being subsidized. Also, the farmers are benefiting greatly from the traditional tank irrigation system. Tank irrigation generally generates higher profit in alfisols than in vertisols. The value of tank command land is about two and a half to four times that of nearby drylands.

Various studies have shown that the efficiency of the traditional tank irrigation system in India is gradually declining owing to: (i) lack of appropriate soil conservation measures in the catchment areas, causing high soil erosion and siltation in the tank; (ii) inadequate maintenance of bunds, waste weirs and delivery channels; (iii) lack of effective water-user organizations; (iv) encroachment of farming on to the tank bed; (v) poor sluice location; (vi) temporal shift in seasonal distribution of rainfall; and (vii) increase in population densities (von Oppen and Subba Rao, 1987). These studies have also indicated the excellent scope for improving the performance of the traditional tank system through appropriate technical inputs and government policies.

\section{Assessment of Adequate Water Availability in the Tank at Critical Crop Growth Stages}

The central problem of water supply for agricultural production is that natural precipitation does not always occur at the right time and of the right magnitude. In many SAT areas, the tanks have been used to supply the muchneeded water for supplemental irrigation. Since the construction of a tank is a costly affair, it is important first to assess the feasibility of water harvesting. For the success of any run-off water harvesting and supplemental irrigation system, this information is highly desirable.

Depending on the balance between the magnitude of run-off from the catchment compared with seepage and evaporation losses, water may or may not be available in the required quantities at the time it is most critically needed. For example, in a study, two tanks located on different alfisol watersheds at the International Crops Research Institute for the Semi-Arid Tropics (ICRISAT), Patancheru, India were selected to assess the prospects of run-off harvesting and water availability. The run-off and water-harvesting models (Pathak et al., 1989; Kumar, 1991) were used to simulate the daily run-off, soil moisture and water availability in the tank. Based on the net water inflow or outflow estimations, daily available water in the tank was calculated. The probability of getting $40 \mathrm{~mm}$ water for irrigation from one of the tanks is large for the major part of the growing season. The conditional probabilities of availability of 20 and $40 \mathrm{~mm}$ water in the tanks for irrigation during periods of drought were also calculated for the tanks. The probabilities of the tank having $40 \mathrm{~mm}$ water for supplemental irrigation during drought periods in July was $68 \%$, while in August and September the probability exceeded $91 \%$. The conditional probabilities of having $20 \mathrm{~mm}$ of irrigation water during drought periods in July, August, September and October exceeded 97\%. Probabilities of occurrence of drought stress at three crop growth stages, namely, growth stage 1 (GS1, sowing to panicle initiation), growth stage 2 (GS2, panicle initiation to anthesis) and growth stage 3 (GS3, grainfilling stage), were estimated (Pathak and Laryea, 1990). In addition, the probability of 
obtaining $40 \mathrm{~mm}$ of water for irrigation from tanks during the drought-stress period for each crop growth stage was also calculated. The chances of $40 \mathrm{~mm}$ of water being available from the tank during drought periods of GS2 and GS3 exceeded $90 \%$ compared with $68 \%$ for GS1.

On vertisols, Pathak and Laryea (1993) used the run-off and water-harvesting models for assessing the prospects of run-off water harvesting at Akola, Maharashtra, India. The waterharvesting model parameters were first calibrated for vertisols. Long-term daily rainfall, open pan evaporation was used, and the probability of getting 40,60, 80 and $100 \mathrm{~mm}$ of water from the tank at different seepage rates was estimated. The probabilities of getting different amounts of water for supplemental irrigation from the tank are shown in Fig. 11.1. The probability of getting water was high for the most part of the crop growing season. However, the high probability of getting $100 \mathrm{~mm}$ irrigation water was limited to only 3 months, i.e. September, October and November. High runoff and low seepage losses were the main reasons for good availability of water in the tank (Fig. 11.2). The 10-year mean water outflow from the tank indicated that there is a possibility of increasing the tank size, since about $2200 \mathrm{~m}^{3}$ run-off water overflows every year from the tank. The probability of occurrence of drought stress at various crop growth stages was estimated. The conditional probability of getting adequate water $(>40 \mathrm{~mm}$ ) for irrigation during drought periods for each crop growth stage was also found to be high (>92\%). The analysis clearly indicates a good prospect of run-off water harvesting in the Akola region of Maharashtra. All this information is useful in developing the strategies for scheduling supplemental irrigation for the Akola region.

Sireesha (2003) assessed the prospects of run-off harvesting in three districts, i.e. Mahabubnagar, Nalgonda and Kurnool districts of Andhra Pradesh, India. The soils at the sites in Mahabubnagar and Nalgonda districts are alfisols, while in Kurnool the soils are vertisols. The water-harvesting model was used in simulating the daily run-off and water availability in the tank. Probabilities of getting 20, 40, 60, 80 and $100 \mathrm{~mm}$ of water for irrigation in the three districts are shown in Fig. 11.3. Results showed that the sites in Nalgonda and Mahabubnagar districts have higher prospects of run-off harvest-

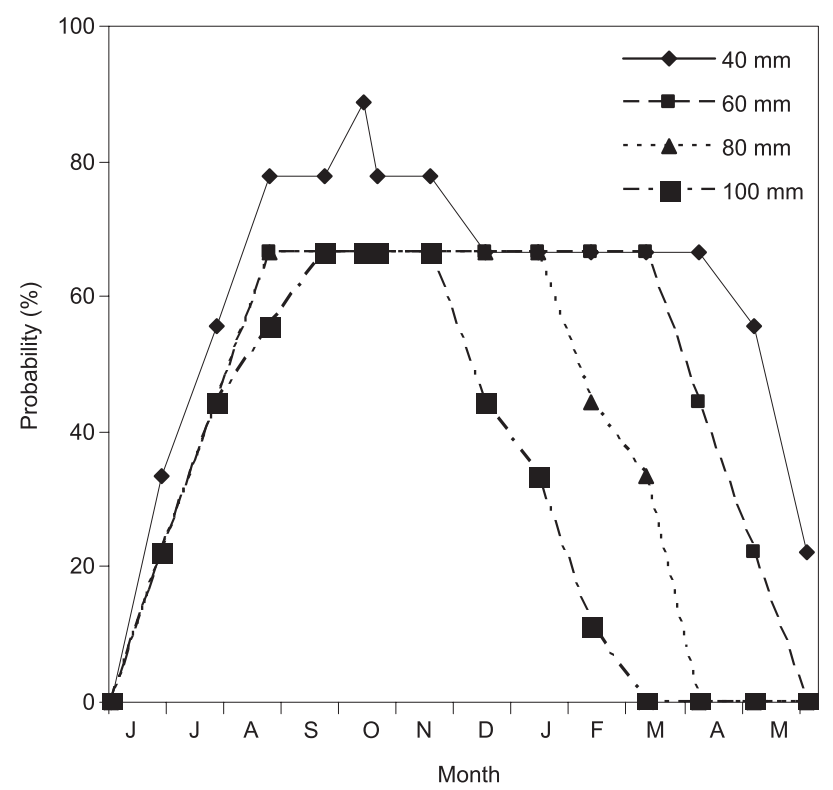

Fig. 11.1. Probabilities of obtaining 40,60, 80 and $100 \mathrm{~mm}$ of water for irrigation from a tank at Akola, Maharashtra, India (based on 10 years of data). 


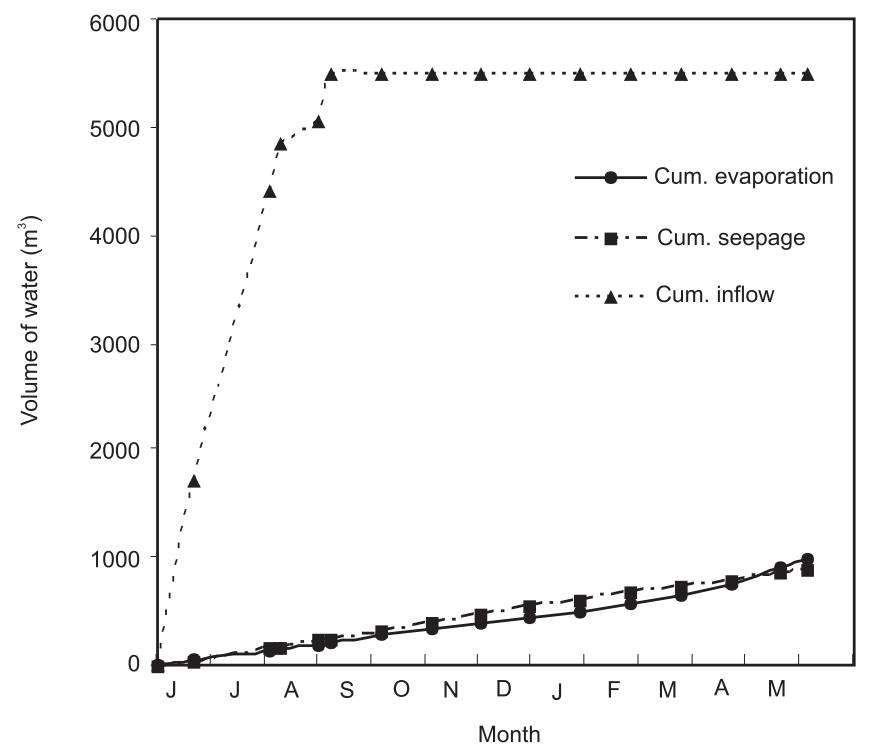

Fig. 11.2. Cumulative inflow, evaporation and seepage losses from a tank at the All India Coordinated Research Project for Dryland Agriculture (AICRPDA) Research Station, Akola, Maharashtra, India.

ing than in Kurnool district. It was found that if the seepage rate exceeds $18.0 \mathrm{l} / \mathrm{m}^{2} /$ day then the probability of getting an adequate amount of water $(40 \mathrm{~mm})$ in the tank was very low (less than $50 \%$ probability). Based on the analysis of soil samples from the three districts, the expected seepage rates should be $3-231 / \mathrm{m}^{2} /$ day.

\section{Optimum Tank Size and Other Design Parameters}

To determine the optimum tank size for a given catchment and crop needs is a difficult task. An excessively large tank size is expensive and may result in making the whole water-harvesting system uneconomical; on the other hand too small a tank cannot meet the irrigation demands at the critical crop stages. Also, we need to consider the expected run-off and water losses, i.e. seepage and evaporation losses from the tank. Therefore, proper sizing of the tank is very important. Several models have been developed and used for estimating the optimum tank size. Some of these models are discussed below.

Sharma and Helweg (1982) developed a methodology to optimally design and locate a small tank in a catchment. They based their computations on irrigation demand of a crop, cost of land under the tank bed, cost of irrigation, seasonal run-off expected, and other catchment descriptions such as area and length.

A simulation model combining a watershed run-off model and a maize grain-yield model was developed to determine the reservoir size necessary to ensure the availability of water on a probability basis for irrigation (Palmer et al., 1982). Return period calculations were made on crop yields to obtain probability curves of yield as a function of reservoir size. It was found that the information generated by the model enabled the user to make informed decisions regarding selection and design of irrigationwater supply reservoirs.

Arnold and Stockle (1991) developed a comprehensive water management model to optimize the pond size for supplemental irrigation. The Simulation for Water Resources in Rural Basins (SWRRB) model was chosen as the basis for the simulation model. This model was modified to simulate crop yield response to supplemental irrigation. A simple economic model was also added. The model was finally linked to a sub-routine to determine the pond size that optimizes average annual return to 


\section{Nalgonda (alfisols)}

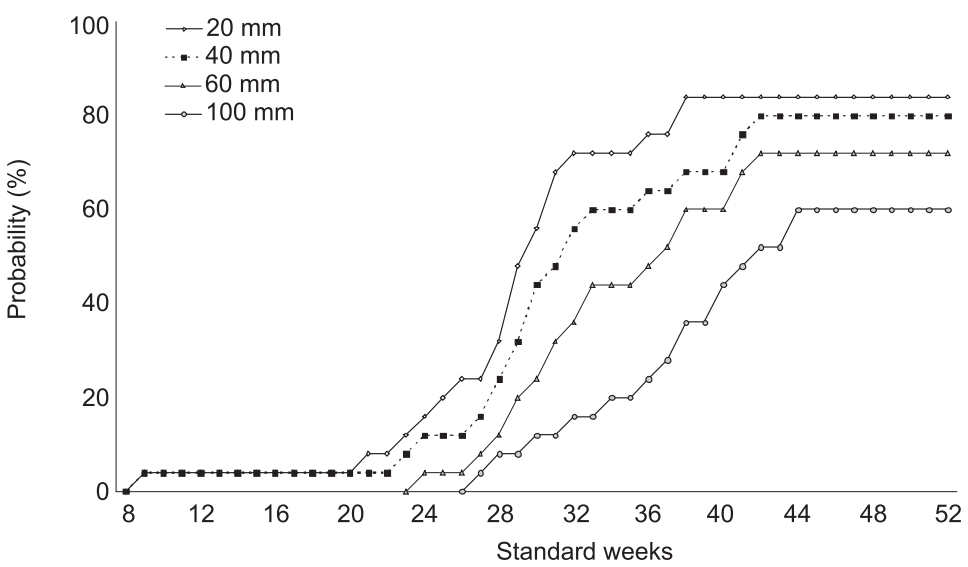

Kurnool (vertisols)

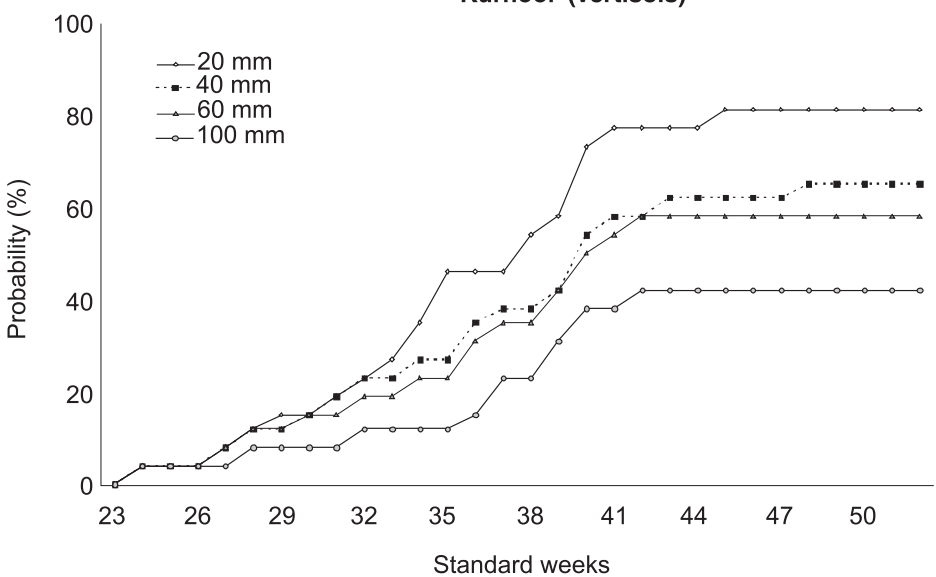

Mahabubnagar (alfisols)

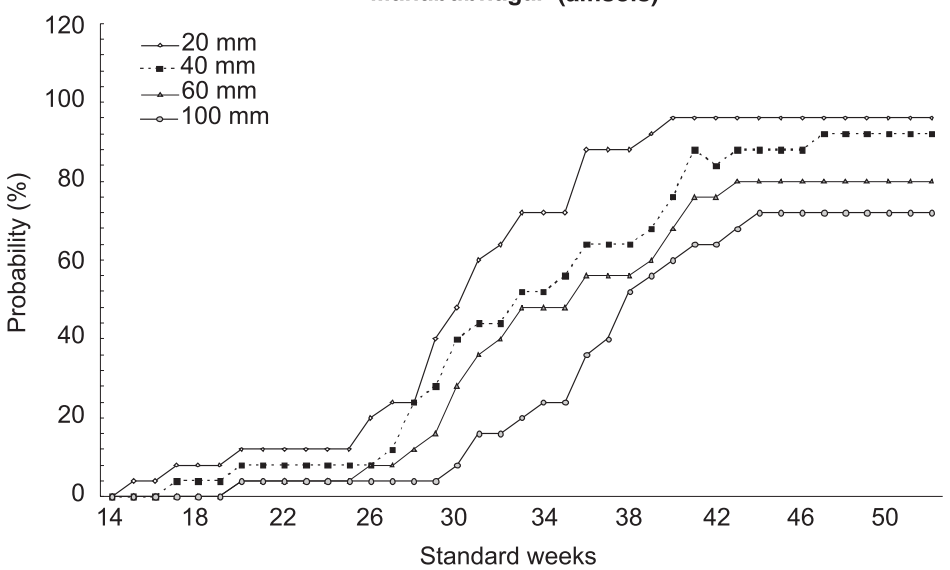

Fig. 11.3. Probabilities of obtaining 20,40,60 and $100 \mathrm{~mm}$ of water in tanks in Nalgonda, Kurnool and Mahabubnagar districts of Andhra Pradesh, India (based on 26 years of simulated data). 
management. The model also develops frequency distribution for risk management. This model has been used to optimize the size of tanks in the USA and elsewhere.

Sireesha (2003) used the water-harvesting model to optimize the tank size for a given catchment and the demand for supplemental irrigation. Optimization functions were used to consider expected run-off, demand for supplemental irrigation, losses from the tank, outflow from the tank and the cost. The most costeffective tank sizes were generally found to be not the ones with too large or too small capacities. Smaller tanks were often not able to meet even minimum supplemental irrigation requirements, while the large tanks were found to be too expensive and the returns above the optimum size were found to be very marginal.

At ICRISAT Center, 13 tanks of different designs and specifications were constructed on vertisols, vertic inceptisols and alfisols. The performance of these tanks varied considerably. The land area occupied by these tanks varied between 3 and $13 \%$ of the catchment area. The storage capacities and area under the tank ranged between 0.1 and 1.2 ha-m, and 0.2 and 0.8 ha, respectively. The storage efficiency was between 1.4 and 2.65 (Sachan and Smith, 1988). A distinctive feature of these tanks is the absence of an outlet structure. After the tank is filled, run-off is automatically diverted to the main waterway.

To achieve overall higher efficiency, the following guidelines should be adopted in the design and construction of run-off storage tanks:

- High storage efficiency (ratio of volume of water storage to excavation): the tank in a gully, depression, or on land having steep slopes. Whenever possible, use the raised inlet system to capture run-off water from upstream. This design will considerably improve the storage efficiency of the structure.

- Reduce the seepage losses: select a tank site having subsoils with low saturated hydraulic conductivity. As a rough guide, the silt and clay content of the least-conducting soil layer is inversely linked with seepage losses. Therefore, it is best to select a site having a subsoil with higher clay and silt and less coarse sand. Also, reduce the tank wetted surface area in relation to water storage volume by making a circular tank.

- Minimize the evaporation losses: as far as possible make the tanks deeper but with an acceptable storage efficiency to reduce watersurface exposure and to use a smaller land area under the tank.

Considerable information on various aspects of run-off water harvesting and supplemental irrigation could be obtained by using these models, i.e. run-off model, water-harvesting model and model for optimizing the tank size. These models can assess the prospects of run-off water harvesting and possible benefits from the irrigation. The models can also be used to estimate the optimum tank size, which is very important for the success of the water-harvesting system. The information generated can also help in developing strategies for scheduling supplemental irrigation, particularly where there is more than one drought during the cropping season (Athavale, 1986; Gunnell and Krishnamurthy, 2003).

\section{Efficient Application of Supplemental Irrigation Water}

In the SAT regions, water is a scarce resource and the amount of water available for supplemental irrigation is generally limited. In such situations, an efficient application of water is very critical as it can contribute significantly to reducing water losses and increasing water use efficiency. Broadly, the methods used for application of irrigation water can be divided into two types, namely surface irrigation systems (border, basin and furrow) and pressurized irrigation systems (sprinkler and drip).

\section{Surface irrigation system}

Currently in the SAT about $96 \%$ of the areas are irrigated using surface flood irrigation. This system is not very efficient and water losses through seepage and evaporation are very high. In the surface irrigation system, the application of irrigation water can be divided in two parts - first, the conveyance of water from its source to the field and, second, application of water in the field. 


\section{Conveyance of water to the field}

In most SAT areas the water is carried to cultivated fields by open channels, which are usually unlined and therefore a large amount of water is lost through seepage. In the absence of proper lining, about $10-35 \%$ of water is lost during conveyance from the source to the field due to seepage and evaporation losses (Singh and Khan, 1999). Several lining materials, e.g. LDPE film, cement-concrete, brick masonry with plaster, slates in cement, soil:cement, soil:silt, asphaltic spray, soil:bentonite, mud plaster, saline sodic soil plaster, prefabricated clay tiles, etc., have been tried to control the seepage losses (Singh and Gupta, 1989; Singh et al., 1999; Singh and Khan, 1999; Fan et al., 2005). Among the materials tried, lining with saline sodic soil, clay plastering, LDPE film and soil:cement proved most promising with regard to their overall performance and the cost of lining. These materials reduced the seepage losses by $35-90 \%$ compared with the unlined channel.

On SAT vertisols, generally there is no need to line the open field channels as the seepage losses in these soils are low, mainly owing to very low saturated hydraulic conductivity $(0.3-1.2 \mathrm{~mm} / \mathrm{h})$ (El-Swaify et al., 1985). On alfisols and other sandy soils having more than $75 \%$ sand, the lining of open field channels or use of irrigation pipes is necessary to reduce the high seepage water losses. The use of closed conduits (plastic, rubber, metallic and cement pipes) is becoming popular, especially with farmers growing highvalue crops, i.e. vegetables and horticultural crops.

\section{Efficient field application of irrigation water}

The efficient application of supplemental water in the field is probably the most important and crucial aspect of the surface irrigation system. The method of surface irrigation plays a vital role in reducing the water losses and in increasing water use efficiency. The major problem with surface flood irrigation relates to uneven distribution of applied water and associated high seepage and evaporation losses. Considerable research work has been done to improve the performance of surface irrigation on different soils and under various topographic conditions.
Improved surface irrigation systems, e.g. border strip, narrow ridge and furrow, broadbed and furrow (BBF), wave-type bed and furrow, compartmental bunding, check basin, limitedirrigation dryland system (LID system) and others, were found to be suitable for different SAT region situations.

EFFICIENT APPLICATION OF SUPPLEMENTAL WATER ON SAT ALFISOLS In alfisols, with common problems of crusting, sealing and hard setting, the efficient application of supplemental water through surface irrigation is a difficult task. On these soils, surface irrigation on flat, cultivated fields results in very poor distribution of water and high water loss. At ICRISAT, Patancheru, India, experiments were conducted to find out the most appropriate land surface configuration for the application of supplemental water. The wave-shaped broadbed, with checks at every $20 \mathrm{~m}$ length along the furrows, was found to be most appropriate for efficient application of supplemental water and increasing crop yields (Table 11.1). It was observed that the moisture distribution across the beds was uniform in the case of wave-shaped broadbeds with checks compared with normal BBF. Sorghum yield in wave-shaped broadbeds with checks was higher at every length of run compared with normal BBF. When irrigation water was applied in the standard BBF system on alfisols, the centre of the broadbed remained dry. The centre crop row did not get sufficient irrigation water, resulting in poor crop yields. In another experiment on alfisols, the standard $\mathrm{BBF}$ system $(150 \mathrm{~cm})$ was compared with the narrow ridge and furrow system $(75 \mathrm{~cm})$. The

Table 11.1. Sorghum grain yield ( $t / h a)$ as affected by the water distribution in different surface irrigation systems on alfisols.

\begin{tabular}{ccc}
\hline $\begin{array}{c}\text { Length } \\
\text { of furrow } \\
(\mathrm{m})\end{array}$ & $\begin{array}{c}\text { Normal } \\
\text { BBF }\end{array}$ & $\begin{array}{c}\text { Wave-shaped } \\
\text { broadbeds } \\
\text { with checks } \\
\text { in furrows }\end{array}$ \\
\hline 0 & 2.07 & 2.52 \\
20 & 2.38 & 3.91 \\
40 & 2.56 & 4.42 \\
60 & 3.06 & 4.54 \\
80 & 3.26 & 4.53 \\
100 & 3.08 & 4.42 \\
\hline
\end{tabular}


narrow ridge and furrow system performed better than the BBF system in terms of both uniform water application and higher crop yields. The water distribution uniformity index (DU $=$ average volume of water infiltrated in the lower one-third length/average volume of water infiltrated) was found to be higher in the narrow ridge and furrow system (0.74) compared with the standard BBF system (0.63). In the flat system, the water distribution uniformity index was in the range of 0.37 to 0.47 . Also, in terms of depth of water application, outflow volume and application efficiency at the various inflow rates, the narrow ridge and furrow system performed better than the standard BBF system (Table 11.2). In the standard BBF system, the outflow volume, even at a low inflow rate of $10 \mathrm{l}$ per min, was high. It was also found that the water application efficiency decreased significantly with increased inflow rates in both narrow ridge and furrow and $\mathrm{BBF}$ systems.

Therefore, for alfisols, the wave-shaped broadbed with checks in the furrows is the most appropriate land-surface configuration for efficient application of supplemental irrigation water, followed by the narrow ridge and furrow system. Also on these soils, low inflow rates should be used to achieve high water application efficiency and reduced outflow volumes (less than $10 \mathrm{l}$ per min).

EFFICIENT APPLICATION OF SUPPLEMENTAL WATER ON SAT VERTISOLS Formation of deep and wide cracks during soil drying is a common feature of SAT vertisols. The abundance of cracks is responsible for high initial infiltration rates (as high as $100 \mathrm{~mm} / \mathrm{h}$ ) in dry vertisols (El-Swaify et al., 1985). This specific feature of vertisols makes efficient application of limited supple- mental water to the entire field a difficult task. At ICRISAT, experiments were conducted on vertisols to find out the appropriate landsurface configuration for efficient application of supplemental irrigation. Among the various systems, the BBF system was found to be most appropriate for applying irrigation water on vertisols. As compared with the narrow ridge and furrow, the BBF saved $45 \%$ of the water without affecting crop yields. Compared with narrow ridge and furrow and flat systems, the BBF system had higher water application efficiency, water distribution uniformity and better soil wetting pattern.

An important feature of the BBF system is the utility of furrows for irrigation water application. However, on SAT vertisols, a considerable amount of irrigation water applied through the furrows is often lost through the cracks present in the furrows. At the ICRISAT Center, studies conducted to evaluate the effect of shallow cultivation in furrows on the efficiency of water application showed that the rate of water advance was substantially higher in cultivated furrows as compared with that in uncultivated furrows (Fig. 11.4). Shallow cultivation in moderately cracked furrows before the application of irrigation water reduced the water required by about $27 \%$, with no significant difference in chickpea yields (Table 11.3).

Also, the water distribution efficiency, opportunity time and depth of water application were found to be higher in the cultivated furrow treatment (Table 11.4). Therefore, for the SAT vertisols, the BBF system seems most appropriate for the efficient application of irrigation water. In case of cracks in the furrow, preirrigation shallow cultivation will make the $\mathrm{BBF}$ system more efficient in terms of both water savings and uniformity of water application.

Table 11.2. Effects of inflow rate on depth of water applied, outflow volume, and application efficiency in different landforms on alfisols.

\begin{tabular}{clccc}
\hline $\begin{array}{c}\text { Inflow } \\
\text { rate }(\mathrm{I} / \mathrm{min})\end{array}$ & Landform & $\begin{array}{c}\text { Depth of water } \\
\text { applied }(\mathrm{cm})\end{array}$ & $\begin{array}{c}\text { Outflow } \\
\text { volume }(\mathrm{I})\end{array}$ & $\begin{array}{c}\text { Water application } \\
\text { efficiency }(\%)\end{array}$ \\
\hline 10 & Narrow ridge and furrow & 3.57 & 14 & 98.7 \\
& BBF & 3.71 & 226 & 94.2 \\
20 & Narrow ridge and furrow & 4.81 & 1217 & 67.0 \\
& BBF & 3.63 & 3402 & 51.6 \\
& Narrow ridge and furrow & 5.15 & 2697 & 48.6 \\
& BBF & 3.50 & 5323 & 39.5 \\
\hline
\end{tabular}




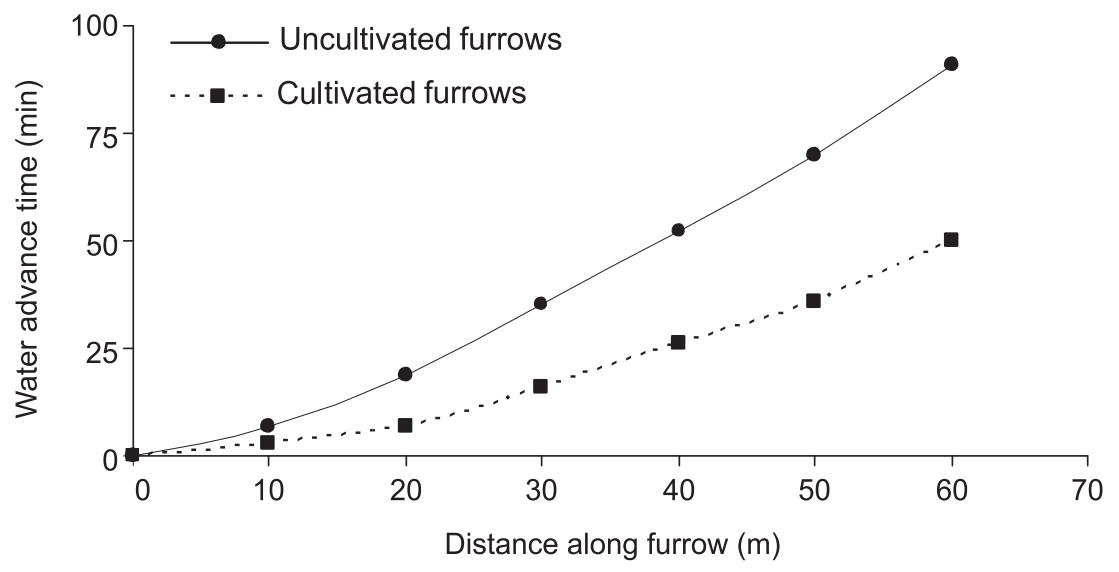

Fig. 11.4. Effect of shallow cultivation in BBF furrow on water advance on vertisols at ICRISAT Center, Patancheru, India.

Table 11.3. Grain yield of chickpea in different treatments on vertisols at ICRISAT Center, Patancheru, India ${ }^{a}$.

\begin{tabular}{lcc}
\hline Treatment & $\begin{array}{c}\text { Mean depth of water } \\
\text { application }(\mathrm{cm})\end{array}$ & Grain yield (kg/ha) \\
\hline No supplemental irrigation & 0 & 690 \\
One supplemental irrigation on uncultivated furrows & 6.3 & 920 \\
One supplemental irrigation on cultivated furrow & 4.6 & 912 \\
SEM & & 19 \\
CV\% & & 5.55
\end{tabular}

a Source: Srivastava et al. (1985).

Table 11.4. Effect of pre-irrigation cultivation in the BBF furrows on opportunity time, water application and water distribution efficiency on vertisols at ICRISAT Center, Patancheru, India ${ }^{a}$.

\begin{tabular}{lccccc}
\hline \multirow{2}{*}{$\begin{array}{l}\text { Distance along } \\
\text { the furrow length }(\mathrm{m})\end{array}$} & \multicolumn{2}{c}{ Uncultivated furrows } & & \multicolumn{2}{c}{ Cultivated furrows } \\
\cline { 2 - 3 } \cline { 5 - 6 } $\begin{array}{c}\text { Opportunity } \\
\text { time }(\mathrm{min})\end{array}$ & $\begin{array}{c}\text { Depth of water } \\
\text { application }(\mathrm{cm})\end{array}$ & & $\begin{array}{c}\text { Opportunity } \\
\text { time }(\mathrm{min})\end{array}$ & $\begin{array}{c}\text { Depth of water } \\
\text { application }(\mathrm{cm})\end{array}$ \\
\hline 0 & 120.0 & 9.5 & & 80.0 & 6.2 \\
10 & 111.9 & 8.8 & & 75.9 & 5.8 \\
20 & 102.7 & 8.2 & & 73.5 & 5.6 \\
30 & 83.8 & 6.5 & & 62.1 & 4.7 \\
40 & 68.4 & 5.2 & & 57.8 & 4.3 \\
50 & 49.1 & 3.6 & & 43.2 & 3.1 \\
60 & 34.0 & 2.3 & & 35.0 & 2.4 \\
Mean water application depth $(\mathrm{cm})$ & & 6.3 & & 4.6 \\
Standard deviation & & 2.53 & & & 7.32 \\
Water distribution efficiency $(\%)$ & & 60 & & \\
\hline
\end{tabular}

a Source: Srivastava et al. (1985). 


\section{Surge flow irrigation system}

Surge flow irrigation is an efficient surface irrigation method, which enhances the water productivity by improving the efficiency of furrow irrigation. This system applies surges of water intermittently rather than in a continuous stream. These surges alternate between two sets of furrows for a fixed amount of time. The alternate wetting and 'resting' time for each surge slows down the intake rate of the wet furrow and produces a smoother and hydraulically improved surface. Thus, the next surge flows more rapidly down the wet furrow until it reaches a dry furrow. Surge irrigation provides more uniform moisture distribution and limits deep percolation losses. Surge flow does not work well on compacted soils, so it is more effective as pre-sowing irrigation and the first irrigation following cultivation. Studies at Tamil Nadu Agricultural University, Coimbatore, India have shown that surge irrigation saves $7-13 \%$ of water and increases water productivity by 19-27\% (Singh, 2007). Surge flow can also save more than $35 \%$ of energy costs compared with simple furrow irrigation (Sharma and Sharma, 2007). Savings in energy and pumping costs can pay for the cost of surge irrigation valves within 2 years. This irrigation system also increases fertilizer application efficiency and lowers salt loading by reducing deep percolation. With proper planning and design this method can be extensively used to efficiently irrigate vegetable crops grown on a ridge and furrow land configuration.

\section{Pressurized irrigation systems}

The traditional surface irrigation methods (flood, border and furrow), which involve water delivery to plants through gravitation, usually result in substantial water losses and limited uniformity in moisture distribution. The improved pressurized irrigation systems enable controlled supply of water at the root zone of the crops (drip method) or aerial sprinkling in the vicinity of the plant (sprinkler method), resulting in a substantial increase in water saving and irrigation efficiency. In these systems, the required quantity of water can be applied more uniformly and precisely at the desired sites, as needed by the crop. Thus, water losses on account of deep percolation or wetting of unwanted soil volume are considerably reduced. In drip irrigation, the decreased wetted surface area results in a significant reduction in evaporation losses, which further augments saving of water. On the other hand, the favourable soil moisture regime owing to controlled application of water and soluble nutrients helps in better crop growth, enhanced yield and superior quality of produce (Singh et al., 1999; Singh, 2007).

SPRINKLER IRRIGATION The sprinkler method of irrigation can be used for the efficient application of supplementary irrigation. Studies have been conducted to evaluate the conventional sprinkler system against the traditional methods of surface irrigation (border, check basin, and furrow irrigation) for various crops (Singh et al., 1999). For tomato crop in sandy loam soils at Madurai, Tamil Nadu, an application of $3.5 \mathrm{~cm}$ water through the sprinkler method gave as much yield as a $6 \mathrm{~cm}$ application by the surface method, thereby saving about $34 \%$ water over 2 years (Table 11.5). For the same $6 \mathrm{~cm}$ irrigation level, the tomato yield in the sprinkler system was higher by $18.6 \%$ compared with the ridge and furrow system.

Recently more efficient sprinkler systems, i.e. low elevation spray application sprinkler (LESA sprinkler) and low energy precision application sprinkler (LEPA sprinkler), have been found to be extremely useful for the efficient application of irrigation water. The LESA sprinkler irrigation systems distribute water directly to the furrow at very low pressure (6-10 psi) through sprinklers positioned $30-45 \mathrm{~cm}$ above ground level. Conventional high-pressure impact sprinklers are positioned 1.5-2.1 $\mathrm{m}$ above the ground, so they are very susceptible to spray evaporation and to wind-drift, causing high water loss and uneven water distribution. The LESA systems apply water in streams rather than fine mists, to eliminate wind-drift and to reduce spray evaporation, deep percolation and underwatering. The LEPA irrigation systems further reduce evaporation by applying water in bubble patterns, or by using drag hoses or drag socks to deliver water directly to the furrow. LEPA and LESA systems concentrate water on a smaller area and increase the water application rate on the areas covered. In addition to water savings, these irrigation systems have been found to use much less 
Table 11.5. Tomato yield as influenced by method and depth of irrigation at Madurai, Tamil Nadu, India, 1995-1997a.

\begin{tabular}{|c|c|c|c|c|c|c|c|}
\hline \multirow[b]{2}{*}{ Method of irrigation } & \multirow{2}{*}{$\begin{array}{c}\text { Depth of } \\
\text { irrigation }(\mathrm{cm})\end{array}$} & \multicolumn{3}{|c|}{ Yield (t/ha) } & \multicolumn{3}{|c|}{ Water applied $(\mathrm{cm})$} \\
\hline & & 1995 & 1996 & Mean & 1995 & 1996 & Mean \\
\hline \multirow[t]{5}{*}{ Sprinkler } & 6.7 & 18.39 & 29.55 & 23.97 & 53.6 & 67.5 & 60.6 \\
\hline & 6.0 & 16.33 & 29.50 & 22.92 & 48.0 & 62.4 & 55.2 \\
\hline & 4.9 & 13.52 & 27.25 & 20.39 & 39.2 & 54.4 & 46.8 \\
\hline & 3.5 & 11.90 & 27.45 & 19.68 & 28.0 & 44.9 & 36.5 \\
\hline & 2.2 & 10.22 & 27.65 & 18.94 & 17.6 & 35.8 & 26.7 \\
\hline Ridge and furrow & 6.0 & 13.84 & 24.80 & 19.32 & 48.0 & 62.4 & 55.2 \\
\hline $\operatorname{CD}(P=0.05)$ & & 1.97 & 3.56 & & & & \\
\hline
\end{tabular}

aSource: Singh et al. (1999).

energy (at least $30 \%$ less than conventional systems), which reduces fuel consumption and operational costs. Other advantages include reduced disease problems due to less wetting of foliage, and easier application of chemicals. Studies have shown that when managed properly, LEPA irrigation is $20-40 \%$ more efficient than typical impact sprinkler systems (Sharma and Sharma, 2007). While LEPA systems can be costly, this expense can be offset in 5-7 years through reduced energy savings of $35-50 \%$, labour-cost reduction and increased crop yields.

DRIP IRRIGATION The area under drip irrigation is fast increasing in India. This is primarily due to its better performance and encouraging government policies. Drip irrigation applies small amounts of water frequently to the soil area surrounding plant roots through flexible tubing with built-in or attached emitters. Subsurface drip irrigation delivers water underground directly to roots. Since water is applied directly to individual plant roots, drip irrigation minimizes or eliminates evaporation, provides a uniform application of water to all plants, and applies chemicals more efficiently. In this irrigation system, a managed amount of water is applied, thereby avoiding deep percolation and run-off while reducing salt accumulation. Drip systems reduce farm operation and maintenance costs through energy savings and automation. Also, drip systems are the only type of irrigation that can use water efficiently on steep slopes, odd-shaped areas and problem soils.

The economics of the system in various crops were studied by evaluating productivity of different planting layouts, crop geometries and system designs to reduce the length of laterals (Sivanappan, 1997; Singh et al., 1999). The results on the comparative performance of the drip system versus surface irrigation for banana are shown in Table 11.6. The application of 241 of water per banana plant on alternate days through drip irrigation produced $31 \mathrm{t} / \mathrm{ha}$ of fruit,

Table 11.6. Banana yields as obtained by different irrigation methods and nitrogen (N) levels at Bhavanisagar, Tamil Nadu, India (average of 1994/95 and 1995/96 data).

\begin{tabular}{lccccc}
\hline & \multicolumn{4}{c}{$\begin{array}{c}\text { Yield (t/ha) at different doses of } \mathrm{N} \\
\text { (g per plant) }\end{array}$} & \\
\cline { 2 - 5 } Irrigation treatment & 80 & 110 & 140 & Mean & Water applied (cm) \\
\hline Alternate day drip irrigation (I/day) & & & & & \\
$\quad 34$ & 30.7 & 30.9 & 31.4 & 31.0 & 96.4 \\
32 & 30.8 & 32.2 & 33.2 & 32.1 & 130.4 \\
40 & 30.7 & 31.6 & 33.7 & 32.0 & 161.8 \\
Mean (drip irrigation) & 30.7 & 31.6 & 32.8 & 31.7 & 129.5 \\
Surface irrigation & 27.3 & 28.4 & 29.2 & 28.3 & 193.6 \\
\hline
\end{tabular}


which was $2.7 \mathrm{t} /$ ha higher than the surface irrigation. In addition, the drip system also saved about $50 \%$ water compared with surface irrigation. In another study conducted at Parbhani (Maharashtra, India) to compare check basin irrigation, the drip irrigation increased the banana yield by $37 \%$ and saved about $32 \%$ water.

Compared with other irrigation systems, namely sprinkler and furrow irrigation, the drip systems provide the most uniform and adequate moisture to the plants (Fig. 11.5). Relative moisture varies the most in furrow irrigation, followed by sprinkler and the least in drip irrigation (Sharma and Sharma, 2007). The drip system is also most efficient in terms of water application efficiency (Table 11.7).

Although drip systems are very efficient, they do have some drawbacks. Because they may clog and are susceptible to damage by rodents, insects and sedimentation, they must be checked regularly. A good filtration system is essential for proper performance of a drip system. Hard water should be treated to discourage mineral build-up. New systems are expensive and must be designed to suit crops and local soil and climate conditions. A reliable, continuous water supply is necessary to run a drip system, and proper irrigation management and furrow shaping is necessary to prevent salt build-up. Rotating crops with different spacing requirements may be problematic after a drip system is installed. Drip irrigation may not be practical for closely spaced annual crops.

The drip irrigation is the most efficient system for the application of supplemental irrigation water. It is most effective in reducing the water losses and increasing irrigation efficiency. It is also the most economical system for high-value crops, i.e. horticultural crops and vegetables. However, the full benefits of irrigation using this system can be achieved by integrating appli-
Table 11.7. Efficiency of different irrigation systems $^{\mathrm{a}}$.

\begin{tabular}{lc}
\hline Irrigation system & $\begin{array}{c}\text { Range of } \\
\text { application } \\
\text { efficiency (\%) }\end{array}$ \\
\hline Drip irrigation & $90-98$ \\
LEPA sprinkler & $90-95$ \\
LESA sprinkler & $80-90$ \\
Surge irrigation & $50-70$ \\
Furrow system & $40-60$ \\
\hline
\end{tabular}

aSource: Sharma and Sharma (2007).

cation of fertilizers and other chemicals with irrigation water, which improves not only water use efficiency but also fertilizer use efficiency. However, its use is very limited for most of the commonly grown annual crops by resourcepoor farmers in the SAT. This is primarily because of the high initial cost of the drip system, which is generally out of reach of poor farmers. Recently, a few promising low-cost drip systems, namely a gravity-fed drip system and a drip system with a low-cost filter, have been manufactured for small farmers.

\section{Conjunctive utilization of rainfall and limited irrigation water}

Stewart et al. (1983) developed a limitedirrigation dryland (LID) system for the efficient use of limited irrigation water for crop production. The objective of the LID system concept is to maximize the combined use of growing-season rainfall, which varies for any given year, with a limited supply of irrigation water. The unique feature of the LID system is the flexible adjustment during the crop growing season of the area of land irrigated, allowing more land to be irrigated during above-average

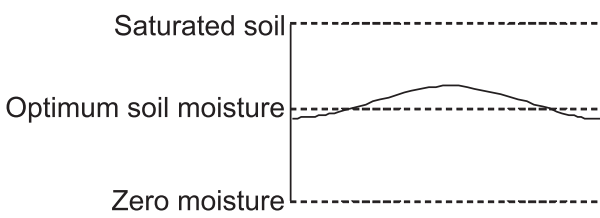

Drip irrigation

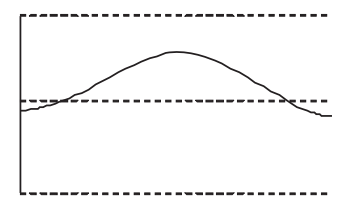

Sprinkler irrigation

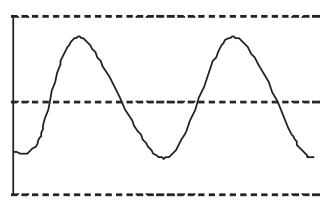

Furrow irrigation

Fig. 11.5. Comparison of soil moisture in different irrigation systems (Source: Sharma and Sharma, 2007). 
rainfall years than during dry or low rainfall years. Risk is low with the LID system, and the crop response is good in favourable rainfall years. This system was adopted and studied at ICRISAT Center, Patancheru, India for rainyseason sorghum on alfisols. It was found that this system is effective in increasing the water application efficiency (WAE) (Table 11.8). Results demonstrated the usefulness of the LID system in the application of limited water under uncertain and erratic rainfall conditions.

Stewart (1989) showed that, using the LID system, higher water use efficiency can be obtained for sorghum and other crops. He also mentioned that to properly use the LID system, the decision makers need to have a good understanding of the relationships of transpiration and evapotranspiration to dry matter and grain yields, and to water application rates. Unless these relationships are understood, it is difficult to make correct decisions regarding the efficient use of irrigation water. Also, these relationships must be further interpreted with regard to risk management and economics, because these factors often dictate decision making.

\section{Crop Responses to Supplemental Irrigation}

Benefits of supplemental irrigation in terms of increasing and stabilizing crop productivity have been impressive, even in the SAT areas with dependable rainfall. Excellent responses to supplemental irrigation have been reported from several locations in India (Gunnell and Krishnamurthy, 2003). For example, Singh et al.
(1999) summarized the response of 13 crops to supplemental irrigation from 23 locations in India. The increase in grain yield over control varied from $23 \%$ in the case of sorghum to $345 \%$ in chickpea. Singh and Khan (1999) also summarized the yield responses of crops to supplemental irrigation in different locations of India; the data indicated that one supplemental irrigation at the critical stages of crop growth considerably increased the crop yields. Introduction of highvalue crops such as hybrid cotton under protective irrigation further helps in enhancing the income of dryland farmers. Owing to better moisture availability through supplemental irrigation, the crops respond to the application of higher rates of nutrients. In an experiment carried out in medium deep black soils at Bijapur, Karnataka, India, the responses of horticultural crops, namely jujube (ber), guava and fig, to supplemental irrigation were studied. The highest $(122.6 \%)$ response to supplemental irrigation was recorded in guava and the lowest $(41.7 \%)$ in fig (Radder et al., 1995). Vijayalakshmi (1987) reported that the effect of supplemental irrigation was largest in rainy-season sorghum and pearl millet, and yields increased by $560 \%$ and $337 \%$; for pigeonpea the yield increased by $560 \%$, but a comparatively lesser response was noted in groundnut, where the yield increased by only $32 \%$ (Table 11.9). For post-rainy-season crops grown at several research stations in India increase in yield by $123 \%$ for wheat, $113 \%$ for barley, $345 \%$ for safflower and $116 \%$ for rapeseed were reported. Havanagi (1982) reported similar crop yield responses to supplemental irrigation from Bangalore (India) research station.

Table 11.8. Effect of irrigation on sorghum (CSH 6) yield $(\mathrm{kg} / \mathrm{ha})$ being obtained on different sections of the slope in alfisols at ICRISAT Center, Patancheru, India, 1985-1986.

\begin{tabular}{|c|c|c|c|c|c|c|c|c|c|c|}
\hline \multirow[b]{2}{*}{ Description ${ }^{a}$} & \multicolumn{2}{|c|}{$\begin{array}{l}\text { Upper section } \\
\qquad(0-20 \mathrm{~m})\end{array}$} & \multicolumn{2}{|c|}{$\begin{array}{l}\text { Middle section } \\
\quad(20-40 \mathrm{~m})\end{array}$} & \multicolumn{2}{|c|}{$\begin{array}{l}\text { Lower section } \\
\qquad(40-60 \mathrm{~m})\end{array}$} & \multicolumn{2}{|c|}{$\begin{array}{c}\text { Average yield } \\
\text { (kg/ha) }\end{array}$} & \multicolumn{2}{|c|}{$\begin{array}{c}\text { WAE } \\
(\mathrm{kg} / \mathrm{mm} / \mathrm{ha})\end{array}$} \\
\hline & 1985 & 1986 & 1985 & 1986 & 1985 & 1986 & 1985 & 1986 & 1985 & 1986 \\
\hline Rainfe & 1058 & 2220 & 1618 & 2110 & 1710 & 2140 & 1659 & 2150 & - & - \\
\hline Full irrigation & 3716 & 3404 & 3516 & 320 & 2960 & 3458 & 3390 & 3352 & 6.9 & 7.5 \\
\hline LID system & 3413 & 3090 & 2600 & 2710 & 2000 & 2110 & 2671 & 2636 & 12.1 & 9.2 \\
\hline
\end{tabular}

a Five irrigations totalling $250 \mathrm{~mm}$ and four irrigations totalling $130 \mathrm{~mm}$ were applied during 1985 and 1986, respectively, on full irrigation and LID (limited-irrigation dryland) system (upper section) treatments on an area basis.

${ }^{\mathrm{b}}$ Water application efficiency (WAE) = Increase in yield due to irrigation 
Table 11.9. Effect of supplemental irrigation on crop yields at different locations in India ${ }^{\text {a }}$.

\begin{tabular}{|c|c|c|c|c|}
\hline Crops & Irrigation (cm) & Yield (t/ha) & $\begin{array}{c}\text { Yield } \\
\text { increase due } \\
\text { to irrigation (\%) }\end{array}$ & $\begin{array}{l}\text { Research } \\
\text { centre }\end{array}$ \\
\hline \multicolumn{5}{|c|}{ Short-duration rainy-season crops } \\
\hline Sorghum & 1.6 & 2.51 & 560 & Hyderabad \\
\hline \multirow[t]{2}{*}{ Maize } & 1 & 2.66 & 15 & Jhansi \\
\hline & 2 & 4.43 & 40 & \\
\hline Finger millet & 5 & 2.32 & 43 & Bangalore \\
\hline Soybean & 8 & 2.05 & 14 & Indore \\
\hline \multicolumn{5}{|c|}{ Long-duration rainy-season crops } \\
\hline Castor & 5 & 1.32 & 31 & Hyderabad \\
\hline Pigeonpea & 3 & 0.17 & 240 & Jhansi \\
\hline (sole crop) & 5 & 0.33 & 560 & \\
\hline Tobacco & 4 & 1.30 & 58 & Dantiwada \\
\hline \multicolumn{5}{|c|}{ Post-rainy-season crops } \\
\hline \multirow[t]{3}{*}{ Wheat } & 2 & 1.58 & 35 & Dehra Dun \\
\hline & 4 & 2.06 & 78 & \\
\hline & 6 & 2.60 & 123 & \\
\hline \multirow[t]{3}{*}{ Rape seed } & 1 & 0.35 & 40 & Ranchi \\
\hline & 3 & 0.46 & 84 & \\
\hline & 5 & 0.54 & 116 & \\
\hline
\end{tabular}

aSource: Vijayalakshmi (1987).

Impressive benefits have been reported from supplemental irrigation on alfisols at ICRISAT Center (El-Swaify et al., 1985; Pathak and Laryea, 1990). As shown in Table 11.10, good yield responses to supplemental irrigation were obtained on alfisols in both rainy and post-rainy seasons. The average WAE for sorghum (14.9 $\mathrm{kg} / \mathrm{mm} / \mathrm{ha}$ ) was more than that for pearl millet (8.8-10.2 kg/mm/ha). Intercropped pigeonpea responded less to irrigation, and the average WAE ranged from 5.3 to $6.7 \mathrm{~kg} / \mathrm{mm} / \mathrm{ha}$ for both pigeonpea/sorghum and pigeonpea/pearl millet systems. Tomatoes responded very well to water application, with an average WAE of $186.3 \mathrm{~kg} / \mathrm{mm} / \mathrm{ha}$.

On vertisols, Srivastava et al. (1985) found that the average WAE was largest for chickpea $(5.6 \mathrm{~kg} / \mathrm{mm} / \mathrm{ha})$, followed by chillies $(4.1 \mathrm{~kg} /$

Table 11.10. Response of cropping systems to supplemental irrigation in an alfisol watershed, ICRISAT Center, Patancheru, India during 1981-1984.

\begin{tabular}{|c|c|c|c|c|c|c|}
\hline $\begin{array}{l}\text { Grain yield } \\
(\mathrm{kg} / \mathrm{ha})^{\mathrm{a}}\end{array}$ & $\begin{array}{l}\text { Increase } \\
\text { due to } \\
\text { irrigation } \\
\text { (kg/ha) }\end{array}$ & $\begin{array}{c}\text { WAE } \\
(\mathrm{kg} / \mathrm{mm} / \mathrm{ha})\end{array}$ & $\begin{array}{l}\text { Grain } \\
\text { yield } \\
(\mathrm{kg} / \mathrm{ha})^{\mathrm{c}}\end{array}$ & $\begin{array}{l}\text { Increase } \\
\text { due to } \\
\text { irrigation } \\
\text { (kg/ha) }\end{array}$ & $\begin{array}{c}\text { WAE } \\
(\mathrm{kg} / \mathrm{mm} / \mathrm{ha})\end{array}$ & $\begin{array}{c}\text { Combined } \\
\text { WAE } \\
(\mathrm{kg} / \mathrm{mm} / \mathrm{ha})\end{array}$ \\
\hline \multicolumn{7}{|c|}{ Intercropping system } \\
\hline Pearl millet & & & Pigeonpea & & & \\
\hline 2,353 & 403 & 10.0 & 1,197 & 423 & 5.3 & 6.8 \\
\hline Sorghum & & & Pigeonpea & & & \\
\hline 3,155 & 595 & 14.9 & 1,220 & 535 & 6.7 & 9.4 \\
\hline \multicolumn{7}{|c|}{ Sequential cropping system } \\
\hline Pearl millet & & & Cowpea & & & \\
\hline 2,577 & 407 & 10.2 & 735 & 425 & 5.3 & 6.9 \\
\hline Pearl millet & & & Tomato & & & \\
\hline 2,215 & 350 & 8.8 & 26,250 & 14,900 & 186.3 & 127.1 \\
\hline
\end{tabular}

aOne irrigation of $40 \mathrm{~mm}$; b ${ }^{\mathrm{W}} \mathrm{WE}$ = water application efficiency; ${ }^{\mathrm{c}}$ Two irrigations of $40 \mathrm{~mm}$ each. 
$\mathrm{mm} / \mathrm{ha})$ and safflower $(2.1 \mathrm{~kg} / \mathrm{mm} / \mathrm{ha})$ (Table 11.11). They concluded from their experiments that irrigation was profitable for sequential crops of chickpea and chillies on vertisols. The WAE was much higher on alfisols than on vertisols (Tables 11.10 and 11.11). A study was conducted at ICRISAT, Patancheru, India to evaluate the water application on earlymaturing pigeonpea for a multiple-harvest system. The results showed that where water supply is limited, irrigation should be given between the main crop and the first ratoon. The yield increase due to two water applications ranged from 500 to $1000 \mathrm{~kg} / \mathrm{ha}$.

Good response to supplemental irrigation had been reported from several parts of SAT Africa (Carter and Miller, 1991; Fox and Rockström, 2000; Bennie and Hensley, 2001; Hatibu, 2003; Jenson et al., 2003; Oweis and Hachum, 2003; Barron, 2004; Rockström et al., 2007). On-farm research in the semi-arid locations in Kenya (Machakos district) and Burkina Faso (Ouagouya) indicates a significant scope for improving water productivity in rainfed farming through supplemental irrigation, especially if the practice is combined with soil fertility management (Barron et al., 1999; Oduor, 2003). The results reported by Rockström et al. (2002) on yields and rainfall use efficiencies ( $\mathrm{kg}$ grain $/ \mathrm{mm}$ rainfall) for sorghum in Burkina Faso and maize in Kenya are shown in Fig. 11.6. Each point represents an average of five replications of water harvesting/fertilizer application treatment for a certain rainy season. In Burkina Faso, on shallow soil with low water-holding capacity, supplemental irrigation alone improved water use efficiency (WUE) (rainfall + irrigation) by $37 \%$ on average (from 0.9 to $1.2 \mathrm{~kg} / \mathrm{mm} / \mathrm{ha}$ ) compared with the control (traditional rainfed practice with manure but no fertilizer). The corresponding figure for the
Kenyan case, on deep soil with high waterholding capacity, was $38 \%$ (from 2.2 to $3.1 \mathrm{~kg}$ / $\mathrm{mm} / \mathrm{ha}$ ). The highest improvement in yield and WUE was achieved by combining supplemental irrigation with fertilizer application. From the experiments in the Sahel region, Fox and Rockström (2003) reported that in sorghum supplemental irrigation alone resulted in a grain yield of $712 \mathrm{~kg} / \mathrm{ha}$, while supplemental irrigation combined with fertilizer application resulted in a grain yield of $1403 \mathrm{~kg} / \mathrm{ha}$, which was higher than the farmer's normal practice by a factor of three (Table 11.12).

Barron (2004) reported from the studies made in Kenya that the water productivity for maize with supplemental irrigation was 1796 $\mathrm{m}^{3} / \mathrm{t}$ of grain, and for maize without supplemental irrigation it was $2254 \mathrm{~m}^{3} / \mathrm{t}$ of grain, i.e. a decrease in water productivity by $25 \%$. The study concluded that the water-harvesting system for supplemental irrigation of maize was found to be both biophysically and economically viable. However, the viability of increased water-harvesting implementation at the catchment scale needs to be assessed so that other downstream uses of water remain uncompromised. Rockström et al. (2007) reported a similar response to supplemented irrigation.

From the above discussion, a large variability in crop responses to supplemental irrigation is apparent at various sites in India and elsewhere. Critically going through the results from different locations, the following key points emerge:

- The best responses to supplemental irrigation were obtained when irrigation water was applied at the critical stages of the crop. The moisture-sensitive periods differ with crop species and varieties; for example, in

Table 11.11. Response of sequential crops to supplemental irrigation in a vertisol watershed at ICRISAT Center, Patancheru, India during 1981-1985a.

\begin{tabular}{lcccc}
\hline & \multicolumn{2}{c}{ Mean yield $(\mathrm{kg} / \mathrm{ha})$} & & \\
\cline { 2 - 3 } Sequential cropping system & $\begin{array}{c}\text { Supplementally } \\
\text { irrigated }\end{array}$ & $\begin{array}{c}\text { Increase due } \\
\text { to irrigation }\end{array}$ & $\begin{array}{c}\text { Water application } \\
\text { efficiency }(\mathrm{kg} / \mathrm{mm} / \mathrm{ha})\end{array}$ \\
\hline 1. Maize + chickpea & 1540 & 493 & 5.6 \\
2. Mung + chillies & 1333 & 325 & 4.1 \\
3. Maize + safflower & 1238 & 165 & 2.1 \\
\hline
\end{tabular}

aSource: Srivastava et al. (1985). 

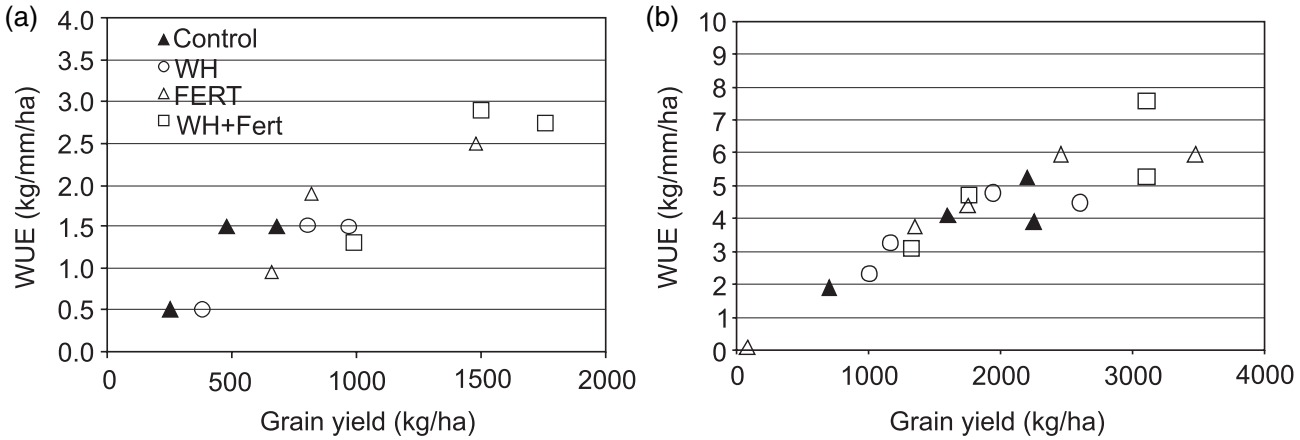

Fig. 11.6. Water use efficiency (WUE) (kg grain per unit rainfall + supplemental irrigation) for (a) sorghum in Burkina Faso, and for (b) maize in Kenya. Note: control = traditional farmers' practice with no fertilizer application; $\mathrm{WH}=$ supplemental irrigation using water harvesting; FERT = fertilizer application (30 kg/ha N); WH+FERT = supplemental irrigation combined with fertilizer application (Source: Rockström et al., 2002).

Table 11.12. Effect of supplemental irrigation and fertilizer on sorghum grain yield $(\mathrm{kg} / \mathrm{ha})$ in Sahel during 1998-2000a .

\begin{tabular}{|c|c|c|c|c|c|c|c|c|}
\hline \multirow[b]{2}{*}{ Treatment $^{\mathrm{b}}$} & \multicolumn{2}{|c|}{1998} & \multicolumn{2}{|c|}{1999} & \multicolumn{2}{|c|}{2000} & \multicolumn{2}{|c|}{ 1998-2000 } \\
\hline & $\begin{array}{l}\text { Mean } \\
\text { yield }^{c}\end{array}$ & $S D^{d}$ & $\begin{array}{l}\text { Mean } \\
\text { yield }^{c}\end{array}$ & $S D^{d}$ & $\begin{array}{l}\text { Mean } \\
\text { yield }^{c}\end{array}$ & $S D^{d}$ & $\begin{array}{l}\text { Mean } \\
\text { yield }^{c}\end{array}$ & $S D^{d}$ \\
\hline TC & $666 \mathrm{a}$ & 154 & $238 a$ & 25 & $460 a$ & 222 & $455 a$ & 232 \\
\hline I & $961 \mathrm{a}$ & 237 & $388 \mathrm{~b}$ & 182 & $787 \mathrm{~b}$ & 230 & $712 \mathrm{~b}$ & 320 \\
\hline$F$ & $1470 \mathrm{~b}$ & 254 & $647 c$ & 55 & $807 \mathrm{~b}$ & 176 & $975 \mathrm{c}$ & 404 \\
\hline IF & $1747 b$ & 215 & $972 \mathrm{~d}$ & 87 & $1489 \mathrm{c}$ & 123 & $1403 d$ & 367 \\
\hline
\end{tabular}

a Source: Fox and Rockström (2003); ${ }^{\mathrm{b}}$ TC = control treatment; I = irrigation application; F = fertilizer application; IF = supplemental irrigation and fertilizer application; ${ }^{c}$ Test of treatment effect: mean values in a column followed by different letters are significantly different at the $5 \%$ level using the Student-Newman-Keul's test; ${ }^{d}$ SD = standard deviation.

sorghum grown in the rainy season, flowering and grain-filling stages are most critical; and in wheat, crown root initiation and grain-filling stages are most critical.

- To get the maximum benefit from supplemental irrigation, factors that limit crop productivity must be removed by using responsive cultivars and fertilizers and following other recommended practices.

- On alfisols and other sandy soils, the best results from the limited supplemental irrigation were obtained during the rainy season. On these soils, the additional benefits from one or two supplemental irrigations during the post-rainy season were found to be limited.

- On vertisols in medium- to high-rainfall areas, pre-sowing irrigation for post-rainy-season crops was found to be the most beneficial. An excellent response to pre-sowing irrigation was recorded in wheat, chickpea, safflower and linseed crops.

- On medium- to high-rainfall vertisol areas, the need for, as well as the response to, supplemental irrigation during the rainy season was not high.

- The crop responses to supplemental irrigation on lighter soils were found to be better than on heavier soils in the low- and medium-rainfall areas. However, this was not true for high-rainfall areas $(<850 \mathrm{~mm})$.

- To get the maximum benefit from the available water, growing high-value crops, namely vegetables and horticultural crops, is becoming popular, even with poor farmers. 


\section{Economic Evaluation of Run-off Storage Structures and Supplemental Irrigation}

At ICRISAT Center, for sorghum/pigeonpea intercrop, two irrigations of $40 \mathrm{~mm}$ each gave an additional gross return of INRs 9750/ha. The highest additional gross return from supplemental irrigation was obtained by growing tomato (INRs 58,300/ha). These results indicate that, on alfisols, significant returns can be obtained from relatively small quantities of supplemental water. In a study conducted in vertisol watersheds at ICRISAT Center, Srivastava et al. (1985) found that average additional gross returns due to supplemental irrigation were about INRs 1630/ha for safflower, INRs 7900/ha for chickpea, and INRs $14,600 /$ ha for chillies. The horticultural system with jujube (ber) plantation at Bijapur gave a gross income of INRs 27,962 to 37,260/ha with two to three supplemental irrigations as against INRs 23,657 to INRs 29,505/ha in control (without irrigation) (Radder et al., 1995).

Singh et al. (1999) reported that the water harvesting and supplemental irrigation system is more economically viable with vegetables, fruits and other high-value crops. Even at 14\% interest, the entire initial investment can be recovered in a period of 2-3 years. Havangi (1982) reported that crops such as chillies, tomato and cowpea responded to protective irrigation, with a benefit-cost ratio in the range of 1.4-2.5. Evaluation of farm ponds at Dehradun showed a benefit-cost ratio of 1.85-1.96, making the farm ponds a viable proposition (Singh and Khan, 1999). Radder et al. (1995) found the water harvesting and supplemental irrigation system economically viable at Bellary research station. Similarly, the research conducted at Bijapur revealed that an annual return of $23 \%$ on the investment was realized from the post-rainy-season sorghum or safflower grown on vertisols with two supplemental irrigations.

The economic evaluation of tank irrigation was done using a simulation model and survey of several tanks and farms from two states in India (Pandey, 1986; von Oppen and Subba Rao, 1987; Pathak and Laryea, 1990). The simulation model consisted of several component modules for rainfall, run-off, soil-water balance, yield response to irrigation and tank- water balance. Simulations were run for selected locations in India using different parameters. Studies indicated that water harvesting in central parts of India is likely to be very profitable even under high seepage rates. Taking the most common cropping system of the region, i.e. a rainy-season fallow followed by post-rainyseason wheat cropping system, Pandey (1986) found that the tanks are quite attractive for the soybean/wheat cropping pattern, even at seepage rates as high as $20 \mathrm{~mm} /$ day. For soybean/ pigeonpea intercrop, tank irrigation is profitable at seepage rates less than $10 \mathrm{~mm} /$ day. At a seepage rate higher than $10 \mathrm{~mm} /$ day, the waterharvesting and supplemental irrigation system was not found to be economical for the soybean/pigeonpea system. Von Oppen and Subba Rao (1987) assessed the economic performance of irrigation tanks in SAT India. It was found that the spatial distribution of tank irrigation is determined primarily by physical conditions, such as hard rock substratum, total and post-monsoon rainfall, and low soil moistureholding capacity. The study also indicated that tanks generally generate higher profits in lighter soils than in heavier soils.

Several studies in Africa have shown that supplemental irrigation systems are affordable and appropriate for single household or small community investments (Rockström et al., 2007). A benefit-cost study on supplemental irrigation of maize-tomato cropping systems in Burkina Faso and Kenya found net profits of US\$73 and US\$390/ha annually, compared with net income losses of US $\$ 165$ and US $\$ 221$ in traditional systems. Moreover, the study found a strong mutual dependence between investments in supplemental irrigation and fertilizers. Studies of supplemental irrigation of maize and cabbage using farm ponds in Kenya (Ngigi et al., 2005) concluded that supplemental irrigation was an economically viable option for improving livelihoods of smallholder farmers. Fox and Rockström (2000) did a benefitcost estimate for the system with storage and use of supplemental irrigation for maize production at the Mwala field site in Kenya. The results showed that current farming systems are not sufficient to meet average household food demand for the conditions prevailing at the site. Depending on how labour cost was estimated, the structure and system of supplemental irri- 
gation and fertilizer were estimated to provide household food self-sufficiency and net income after 1-7 years. The most profitable estimate was for no labour cost and thin plastic sheeting as a sealant. In the overall assessment, Barron (2004) found that the water-harvesting system for supplemental irrigation of maize was both biophysically and economically viable. However, the adoption by farmers depends on other factors, including investment capacity, know-how, and policy and legislative possibilities. The viability of increased water-harvesting implementation at a catchment scale needs to be assessed so that other downstream uses of water are not compromised.

\section{Watershed-based Water Harvesting, Groundwater Recharging and Efficient Water Utilization}

Upgrading rainfed agriculture is key for increasing agricultural productivity and improving livelihoods of farmers. In SAT, supplemental irrigation is of critical importance, particularly in reducing the risk associated with the dry spells. However, to maximize the benefits from the water, a more integrated approach is needed. Also in rainfed agriculture, where water is a highly variable production factor, risk reduction through integrated water management is a key to unlocking the potential of managing crops, soil fertility and pests, and allowing for diversification. For rainfed agriculture, the watershed provides a logical hydrological scale for effectively managing the rainfall, run-off and groundwater. A review of 311 case studies of watershed programmes in India by ICRISAT revealed that they are 'silently' rejuvenating rainfed areas with a mean benefit-cost ratio of 2.14 and an internal rate of return of $22 \%$. Watershed programmes have increased water availability, augmented the irrigated area and cropping intensity, and created employment opportunities (Wani et al., 2003a).

Although the integrated watershed programme includes multifaceted activities, water harvesting, groundwater recharging and its efficient utilization have been the key components of most watershed programmes in India and other Asian countries. Results from some key watershed programmes with reference to these aspects are discussed.
ICRISAT, in partnership with the National Agricultural Research Systems (NARS) in Asia, has developed an innovative and upscalable consortium model for managing watersheds holistically (Wani et al., 2003b). The approach uses rainwater management as an entry-point activity, starting with in-situ conservation of rainwater, harvesting and groundwater recharging the excess run-off, and converging the benefits of stored rainwater into increased productivity by using improved crops, cultivars, suitable nutrient and pest management practices, and land and water management practices. The consortium strategy brings together institutions from the scientific, non-government, government, and farmers' groups for knowledge management. Convergence allows integration and negotiation of ideas among actors. Cooperation enjoins all stakeholders to harness the power of collective actions. Capacity building engages in empowerment for sustainability. This approach of integrated and participatory watershed development and management has emerged as the cornerstone of rural development in the semi-arid tropics. It ties together the biophysical notion of a watershed as a hydrological unit with the social aspect of community and its institutions for sustainable management of land, water and other resources.

At ICRISAT benchmark watersheds in India, Thailand, Vietnam and China, community- and farmer-based soil and water conservation interventions, such as check-dams, gabions and gully control structures, field bunding and percolation pits, were undertaken to improve the surface and groundwater availability. Findings in most of the watershed sites revealed that open wells located near water-harvesting structures (WHS) have significantly higher water levels compared with those away from WHS (Fig. 11.7). Also the increased availability of water in wells encouraged farmers to invest more to acquire improved irrigation facilities (Table 11.13). In Tad Fa and Wang Chai watersheds in north-east Thailand, a $45 \%$ increase in farm incomes was observed within 3 years of the watershed project. Farmers earned an average net income of US\$1195 per cropping season. In Thanh Ha watershed, Vietnam, collective pumping of well water and establishing an efficient water-distribution system enabled the farmers' group to earn more 

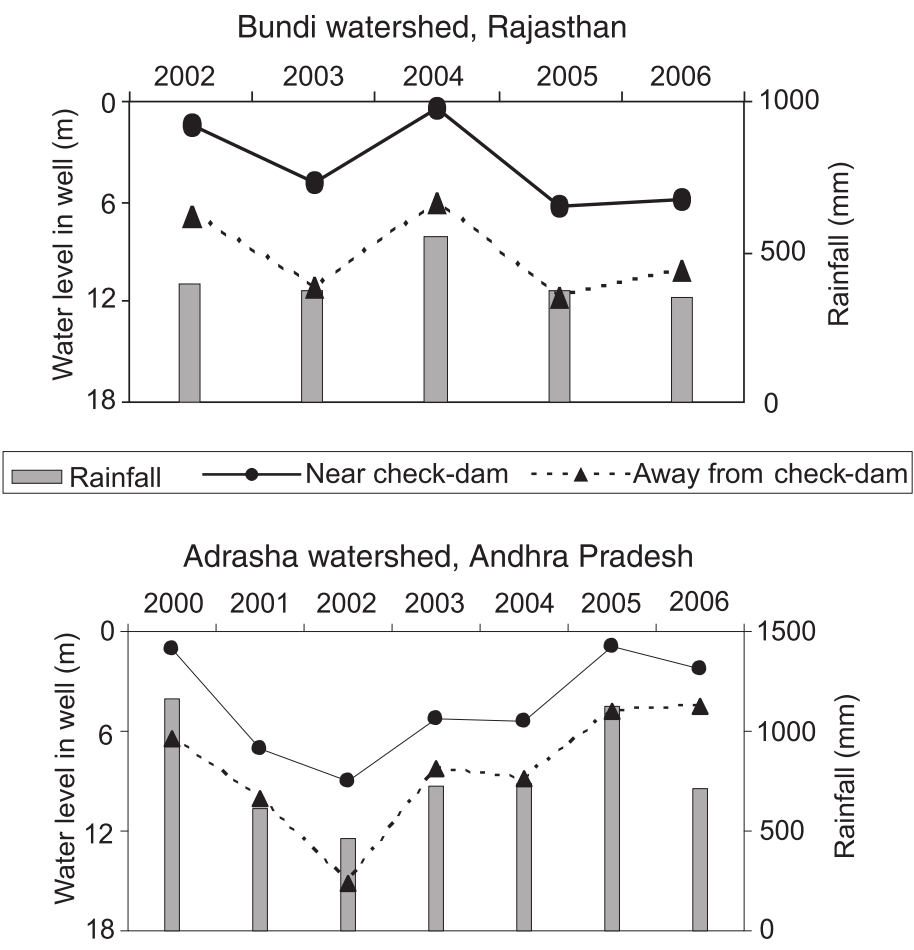

$\square$ Rainfall $\longrightarrow$ Near check-dam - - - - - - Away from check-dam

Fig. 11.7. The impact of watershed interventions on groundwater levels at two benchmark sites in India.

Table 11.13. Effect of watershed programme on irrigation equipment at the Gokulpura-Goverdhanpura watershed, Bundi, Rajasthan, India ${ }^{a}$.

\begin{tabular}{|c|c|c|c|c|}
\hline \multirow[b]{2}{*}{ Irrigation equipment ${ }^{\mathrm{b}}$} & \multicolumn{2}{|c|}{ Before watershed interventions } & \multicolumn{2}{|c|}{ After watershed interventions } \\
\hline & $\begin{array}{l}\text { Number of } \\
\text { equipment }\end{array}$ & $\begin{array}{l}\text { Number of } \\
\text { families }\end{array}$ & $\begin{array}{l}\text { Number of } \\
\text { equipment }\end{array}$ & $\begin{array}{c}\text { Number of } \\
\text { families }\end{array}$ \\
\hline Chadas (traditional method) & 164 & 221 & 110 & 151 \\
\hline Diesel pumps & 79 & 145 & 139 & 202 \\
\hline Electric pumps & 8 & 18 & 11 & 18 \\
\hline Pipeline length (m) & 1685 & 50 & 5982 & 82 \\
\hline
\end{tabular}

aSource: Pathak et al. (2007); ' Some equipment was jointly owned by the families.

income by growing watermelon, with reduced drudgery for women, who had to carry water on their heads from a long distance. Pumping of water from the river as a means to irrigate watermelon has provided maximum income for households. Improved water availability in the watershed not only resulted in increased crop productivity but a significant shift in area under cultivation took place towards high-value cereals, cash crops, vegetables, flowers and fruits.

At Fakot in Tehri Garhwal district, India, a 370 ha watershed was treated with various waterharvesting and soil conservation measures. Consequently, paddy and wheat yields increased by $1.65 \mathrm{t} / \mathrm{ha}$ and $1.93 \mathrm{t} / \mathrm{ha}$, respectively. These 
measures considerably reduced run-off and soil loss from 42.0 to $0.7 \%$ and 11.0 to $2.7 \mathrm{t} / \mathrm{ha}$, respectively. The B:C ratio, considering 25 years' project life, has been worked out as 2.71 at $12 \%$ discount rate (Sharda and Juyal, 2007).

At Salaiyur watershed in Coimbatore district, India, a total of 266 ha-cm additional rainwater storage capacity was created by rejuvenation of existing ponds and construction of new checkdams and percolation ponds on community and private lands through involvement of the watershed committee (Sikka et al., 2004). This helped in augmenting groundwater recharge and improving availability of water in the wells through recuperation, which ultimately resulted in increased area under irrigation and crop diversification with high-value crops.

At Kokriguda watershed, Koraput district, Orissa, India, various soil and water conservation measures were implemented to improve water availability and control soil erosion. A water users' association was constituted to maintain the various structures. Open wells registered a water table rise of $0.32 \mathrm{~m}$ and crop yields increased by $15 \%$ in finger millet to $38 \%$ in upland paddy. Owing to these interventions, the area under remunerative crops like vegetables increased from 2 to 35 ha, conveyance efficiency from 23 to $95 \%$ and overall irrigation efficiency from 20 to $43 \%$ (Patnaik et al., 2004).

In the Rajiv Gandhi watershed programme in Madhya Pradesh, India, over 0.7 million WHS were constructed. The programme ran on a mission mode and had over $19 \%$ people's contribution in monetary terms. There has been a $59 \%$ increase in irrigated area and a $34 \%$ decrease in wasteland area where the mission has worked. The agricultural production in the project villages increased by $37 \%$ during the rainy season and by $30 \%$ during the post-rainy season. Over 3000 villages have reported accretion in groundwater.

The above results from the integrated watershed programmes clearly indicate the excellent opportunities of implementing water harvesting, groundwater recharging and supplemental irrigation at a watershed scale. The key advantage of this approach is that these interventions can be implemented both at farmers' field level as well as community level. Also the watershedbased community organizations and institutions assist in sustainable management of WHS.

\section{Summary and Conclusions}

The SAT regions are facing multifaceted problems of water shortage, land degradation, severe poverty and escalating population pressure. Clearly there is an imbalance between natural resources, population and basic human needs in the SAT regions. If agricultural production and livelihoods are to be improved and sustained the limited rainwater available to agriculture has to be used more efficiently for increasing productivity. This can be achieved only by upgrading the current low-input rainfed agriculture. However, upgrading rainfed agriculture will require substantial investments, which is difficult unless the risk associated with drought is reduced substantially. Water harvesting and supplemental irrigation can play a critical role in reducing the risk associated with drought. This implies that the investments in water management can be used as an entry point to unlock the potential of SAT agriculture. Research work from Asia and sub-Saharan Africa clearly shows that run-off harvesting is feasible and is a profitable practice in most areas. Considerable research information in the field exists. The available information is sufficient for many regions for developing sustainable water-harvesting and supplemental irrigation systems. The greatest challenge is to use the existing knowledge in the planning and execution of a water-harvesting and supplemental irrigation system.

The efficiency of traditional tank irrigation in SAT India is gradually declining. The total area under tank irrigation is declining due to low efficiency in storage and conveyance, and poor maintenance primarily due to social and organizational problems. There is excellent scope and urgent need of improving this traditional tank system for irrigating rainfed systems.

The first important aspect of water harvesting is to assess its feasibility. Considerable information on various aspects of run-off water harvesting and supplemental irrigation could be obtained by using available models, i.e. run-off model, water-harvesting model and model for optimizing of tank size. These models can assess the prospects of run-off water harvesting and possible benefits from irrigation. These models can be also used to estimate the 
optimum tank size, which is extremely important for economic viability of the waterharvesting system. The information generated can also help in developing the strategies for scheduling supplemental irrigation. However, some of these models may require calibration before they can be used. The availability of appropriate data for model calibration could be a limiting factor in some SAT areas.

Efficient application of supplemental irrigation water is extremely crucial. In the past this aspect has been neglected. Currently major water losses $(>40 \%)$ and poor uniformity in water distribution are occurring due to inappropriate surface irrigation methods. Using the current knowledge, considerable improvement in the performance of surface irrigation methods is possible. For SAT alfisols, the wave-shaped broadbed with checks in furrows is the most appropriate land-surface configuration for efficient application of supplemental irrigation water, followed by the narrow ridge and furrow system. For SAT vertisols, the standard BBF system is most appropriate for the application of irrigation water. In the presence of cracks in the furrows, shallow cultivation before irrigation is recommended for reducing water losses and improving uniformity of water application. The improved surge flow irrigation method can also be used for improving the performance of furrow irrigation. This system saves water, uses less energy and improves water productivity. With proper planning and design, the surge flow system can be extensively used for efficiently irrigating high-value crops grown on the ridge and furrow landform. The modern irrigation methods, namely sprinklers and drip irrigation, can play vital roles in improving water productivity. These irrigation systems are highly efficient in water application and have opened up opportunities to cultivate light-textured soils with very low water-holding capacity and in irrigating undulating farmlands. The technology has also enabled regions facing limited water supplies to shift from low-value crops with high water requirements, such as cereals, to highvalue crops with moderate water requirements, such as fruits and vegetables. Implementation of these improved irrigation techniques can be used to save water and energy, and increase crop yields. However, currently the use of these improved irrigation methods is limited, primarily due to the high initial cost. Favourable government policies and the availability of credit are essential for popularization of these irrigation methods.

Impressive benefits have been reported from supplemental irrigation in terms of both increasing and stabilizing crop productivity from many parts of SAT Asia and Africa. The best response to supplemental irrigation was obtained when water was applied at the critical stages of crops. Even small amounts of water applied $(10-15 \mathrm{~mm})$ at critical growth stages were highly beneficial. To get the maximum benefits from supplemental irrigation other improved inputs, e.g. responsive cultivars, fertilizers, etc., must be used. On low water-holding-capacity soils, the best response from irrigation was obtained during the rainy season. On such soils, the benefits from one or two irrigations during the postrainy season were found to be limited. On the other hand, on high moisture-holding-capacity soils, the supplemental irrigation responses during the rainy season were not very attractive. On these soils, pre-sowing irrigation for postrainy-season crops was highly beneficial.

The water harvesting and supplemental irrigation systems were found to be economically viable for most SAT crops. Higher benefits were recorded with vegetables, fruits and other highvalue crops. The economic viability of the water-harvesting systems was found to be highly linked with the seepage rates. At high seepage rates the system was not economically viable for low-value crops. In SAT Africa, the economic viability of supplemental irrigation was linked to the application of fertilizers and other improved practices.

Finally, there is a need to have a new paradigm for water management in the SAT areas, where at watershed scale water needs to be managed in an integrated manner from rainfed to supplemental irrigation using harvested runoff water or recharged groundwater. Evidence from various integrated watershed projects in India clearly shows the excellent scope of runoff water harvesting, groundwater recharging and efficient utilization at the watershed scale. This approach provides greater opportunity for improving water availability for supplemental irrigation and sustaining the water-storage structures through community participation and institutional support. 


\section{References}

Arnold, J.G. and Stockle, C. (1991) Simulation of supplemental irrigation from on-farm ponds. Journal of Irrigation and Drainage Engineering 117(3), 408-424.

Athavale, R.N. (1986) Hydrological basis of a strategy for scheduling supplementary irrigation to cereal crops in dryland agriculture. In: Kanwar, J.S. (ed.) Proceedings of Symposium of National Seminar on Water Management - the Key to Developing Agriculture, 28-30 April 1986, National Science Academy, New Delhi, India. Agricole Publishing Academy, New Delhi, India, pp. 250-275.

Barron, J. (2004) Dry spell mitigation to upgrade semi-arid rainfed agriculture: water harvesting and soil nutrient management. PhD thesis, Natural Resources Management, Department of Systems Ecology, Stockholm University, Stockholm, Sweden.

Barron, J., Rockström, J. and Gichuki, F. (1999) Rainwater management for dry spell mitigation in semi-arid Kenya. East African Agriculture and Forestry Journal 65(1), 57-69.

Bennie, A.T.P. and Hensley, M. (2001) Maximizing precipitation utilization in dryland agriculture in South Africa - a review. Journal of Hydrology 241, 124-139.

Carter, D.C. and Miller, S. (1991) Three years with an on-farm macro-catchment water harvesting system in Botswana. Agricultural Water Management 19, 191-203.

El-Swaify, S.A., Pathak, P., Rego, T.J. and Singh, S. (1985) Soil management for optimized productivity under rainfed conditions in the semi-arid tropics. Advances in Soil Science 1, 1-64.

Fan, T., Stewart, B.A., Payne, W.A., Wang, Y., Song, S., Luo, L. and Robinson, C.A. (2005) Supplemental irrigation and water-yield relationships for plasticulture crops in the loess plateau of China. Agronomy Journal 97, 177-188.

FAO (Food and Agriculture Organization of the United Nations) (2002) World Agriculture: Towards 2015/2030: Summary Report. FAO, Rome, Italy.

Fox, P. and Rockström, J. (2000) Water harvesting for supplemental irrigation of cereal crops to overcome intra-seasonal dry-spells in the Sahel. Physics and Chemistry of the Earth, Part B Hydrology, Oceans and Atmosphere 25(3), 289-296.

Fox, P. and Rockström, J. (2003) Supplemental irrigation for dry-spell mitigation of rainfed agriculture in the Sahel. Agricultural Water Management 61(1), 29-50.

Gunnell, Y. and Krishnamurthy, A. (2003) Past and present status of run-off harvesting systems in dryland peninsular India: a critical review. Ambio 32(4), 320-323.

Hatibu, N. (2003) Rainwater management: strategies for improving water availability and productivity in semi-arid and arid areas. In: Issues of Water Management in Agriculture: Compilation of Essays, Comprehensive Assessment of Water Management in Agriculture. International Water Management Institute (IWMI), Colombo, Sri Lanka. http://www.iwmi.org/assessment\%20

Havanagi, G.V. (1982) Water harvesting and life saving irrigation for increasing crop production areas of Karnataka. In: Proceedings of the Symposium on Rainwater and Dryland Agriculture. Indian National Science Academy (INSA), New Delhi, India, pp. 159-170.

Jenson, J.R., Bernhard, R.H., Hansen, S., McDonagh, J., Moberg, J.P., Nielsen, N.E. and Nordbo, E. (2003) Productivity in maize based cropping systems under various soil-water-nutrient management strategies in a semi-arid, Alfisol environment in East Africa. Agricultural Water Management 59, 217-237.

Kumar, A. (1991) Modeling run-off storage for small watersheds. MTech thesis, Asian Institute of Technology, Bangkok, Thailand.

Ngigi, S.N, Savenije, H.H.G., Thome, J.N., Rockström, J. and Penning de Vries, F.W.T. (2005) Agrohydrological evaluation of on-farm rainwater storage systems for supplementary irrigation in Laikipia district of Kenya. Agricultural Water Management 73(1), 21-41.

Oduor, A. (2003) Hydrological assessment of run-off catchment schemes: a case of water harvesting using underground innovative tanks for supplementary irrigation in semi-arid Kenya. MSc thesis. WERM 03,04, UNESCO-IHE, Delft, the Netherlands.

Oweis, T. and Hachum, A. (2003) Improving water productivity in dry areas of West Asia and North Africa. In: Kijne, J.W., Barker, R. and Molden, D. (eds) Water Productivity in Agriculture: Limits and Opportunities for Improvement. CAB International, Wallingford, UK, pp. 179-198.

Palmer, W.L., Barfield, B.J. and Haon, C.T. (1982) Sizing farm reservoirs for supplemental irrigation of corn. Part I: modelling reservoir size yield relationship. Transactions of American Society of Agricultural Engineers 25, 372-376.

Pandey, S. (1986) Economics of water harvesting and supplementary irrigation in the semi-arid tropics of India: a systems approach. PhD thesis, University of New England, Australia. 
Pathak, P. and Laryea, K.B. (1990) Prospects of water harvesting and its utilization for agriculture in the semiarid tropics. In: Proceedings of Symposium of the SADCC (Southern African Development Coordination Conference), 8-10 October 1990. Land and Water Management Research Program, Gaborone, Botswana, pp. 266-278.

Pathak, P. and Laryea, K.B. (1993) Runoff water harvesting and supplemental irrigation in SAT. In: Resource Management Program Annual Report. International Crops Research Institute for the Semi-Arid Tropics (ICRISAT), Patancheru, India, pp. 56-58.

Pathak, P., Laryea, K.B. and Sudi, R. (1989) A run-off model for small watersheds in the semi-arid tropics. Transactions of American Society of Agricultural Engineers 32, 1619-1624.

Pathak, P., Wani, S.P., Sudi, R., Chourasia, A.K., Singh, S.N. and Kesava Rao, A.V.R. (2007) Rural prosperity through integrated watershed management: a case study of Gokulpura-Goverdhanapura in Eastern Rajasthan. Global Theme on Agroecosystems Report No. 36. International Crops Research Institute for the Semi-Arid Tropics (ICRISAT), Patancheru, India.

Patnaik, U.S., Choudary, P.R., Sudhishri, S., Dass, A. and Paikaray, N.K. (2004) Participatory Watershed Management for Sustainable Development in Kokriguda watershed, Koraput, Orissa. CSWCRTI, Research Centre, Sunabeda, India.

Radder, G.D., Itnal, C.J. and Belgaumi, M.I. (1995) Protective irrigation (life saving) - principles and practices. In: Singh, R.P. (ed.) Sustainable Development of Dryland Agriculture in India. Scientific Publishers, Jodhpur, India.

Rockström, J., Barron, J. and Fox, P. (2002) Rainwater management for increased productivity among smallholder farmers in drought prone environments. Physics and Chemistry of the Earth 27, 949-959.

Rockström, J., Hatibu, N., Oweis, T.Y. and Wani, S.P. (2007) Managing water in agriculture. In: Molden, D. (ed.) Water for Food, Water for Life: a Comprehensive Assessment of Water Management in Agriculture. International Water Management Institute (IWMI), Colombo, Sri Lanka, pp. 315-352.

Sachan, R.C. and Smith, G.D. (1988) Runoff collection and use in rainfed agriculture - the ICRISAT experience. Consultation on Supplementary Irrigation, Rabat (Morocco), 7-9 December 1987. Food and Agriculture Organization of the United Nations, Rome, Italy, pp. 27-40.

Sharda, V.N. and Juyal, G.P. (2007) Rainwater harvesting, groundwater recharge and efficient use in high rainfall areas. In: Ensuring Water and Environment for Prosperity and Posterity Souvenir. 10th InterRegional Conference on Water and Environment (ENVIROWAT 2007), 17-20 October 2007, organized by Indian Society of Water Management in collaboration with Indian Society of Agricultural Engineers and International Commission on Agricultural Engineering, pp. 59-70.

Sharma, K.D. and Sharma, A. (2007) Strategies for optimization of groundwater use for irrigation. In: Ensuring Water and Environment for Prosperity and Posterity Souvenir. 10th Inter-Regional Conference on Water and Environment (ENVIROWAT 2007), 17-20 October 2007, organized by Indian Society of Water Management in collaboration with Indian Society of Agricultural Engineers and International Commission on Agricultural Engineering, pp. 52-58.

Sharma, P.N. and Helweg, O.J. (1982) Optimal design of a small reservoir system. ASCE Journal of Irrigation and Drainage IR4, 250-264.

Sikka, A.K., Madhu, M., Chand, S., Selvi, V., Singh, D.V., Sundarambal, P. and Jeevarathnam, K. (2004) Participatory Watershed Management for Sustainable Development in Salaiyur Watershed, Coimbatore, Tamil Nadu. CSWCRTI, Research Centre, Udhagamandalam, India.

Singh, H.P. (2007) Enhancing water productivity in horticultural crops. In: Ensuring Water and Environment for Prosperity and Posterity Souvenir. 10th Inter-Regional Conference on Water and Environment (ENVIROWAT 2007), 17-20 October 2007, organized by Indian Society of Water Management in collaboration with Indian Society of Agricultural Engineers and International Commission on Agricultural Engineering, pp. 40-48.

Singh, H.P. and Gupta, J.P. (1989) Scope of water harvesting and control of water losses in deep percolation. In: International Symposium on Managing Sandy Soils, 6-10 February 1989, Central Arid Zone Research Institute (CAZRI), Jodhpur, India.

Singh, R.P. and Khan, M.A. (1999) Rainwater management: water harvesting and its efficient utilization. In: Singh, H.P., Ramakrishna, Y.S. and Venkateswaralu, B. (eds) Fifty Years of Dryland Agricultural Research In India. Central Research Institute for Dryland Agriculture (CRIDA), Hyderabad, India, pp. 301-313.

Singh, S.R., Chaudhary, T.N., Bhatta, R.K., Bhatnagar, P.R., Saha, B. and Patil, N.G. (1999) Irrigation water management. In: Singh, G.B. and Sharma, B.R. (eds) Fifty Years of Natural Resource Management Research in India. Central Soil Salinity Research Institute (CSSRI), Karnal, India, pp. 40-48. 
Sireesha, P. (2003) Prospects of water harvesting in three districts of Andhra Pradesh. MTech thesis, Centre for Water Resources, Jawaharlal Nehru Technological University (JNTU), Hyderabad, India.

Sivanappan, R.K. (1997) State of the art in the area of water harvesting in semi arid parts of the world. Presented at the Workshop on Water Harvesting for Supplementary Irrigation of Staple Food Crops in Rainfed Agriculture, Stockholm University, Stockholm, Sweden.

SIWI (2000) Water Harvesting for Upgrading of Rainfed Agriculture: Problem Analysis and Research Needs. Persson, G. (ed.), SIWI, Stockholm, Sweden.

Srivastava, K.L., Pathak, P., Kanwar, J.S. and Singh, R.P. (1985) Watershed-based soil and rain water management with special reference to Vertisols and Alfisols. Presented at the National Seminar on Soil Conservation and Watershed Management, 5-7 September 1985, New Delhi, India.

Stewart, B.A. (1989) Limited-irrigation/dryland farming systems for efficient water management in semi-arid environments. In: Management of Vertisols for Improved Agricultural Production: Proceedings of an IBSRAM Inaugural Workshop, 18-22 February 1985. International Crops Research Institute for the SemiArid Tropics (ICRISAT), Patancheru, India, pp.101-112.

Stewart, B.A., Musick, J.T. and Dusek, D.A. (1983) Yield and water use efficiency of grain sorghum in a limited irrigation-dryland system. Agronomy Journal 75, 629-634.

Troll, C. (1965) Seasonal climates of the Earth. In: Rodenwaldt, E. and Jusatz, H. (eds) World Maps of Climatology. Springer-Verlag, Berlin.

Vijayalakshmi, K. (1987) Soil management for increasing productivity in semi-arid red soils: physical aspects. In: Pathak, P., El-Swaify, S.A. and Singh Sardar (eds) Proceedings of the Consultant's Workshop on the State of the Art and Management Alternatives for Optimizing the Productivity of SAT Alfisols and Related Soils, 1-3 December 1983. International Crops Research Institute for the Semi-Arid Tropics (ICRISAT), Patancheru, India, pp. 109-115.

von Oppen, M. and Subba Rao, K.V. (1987) Tank irrigation in semi-arid tropical India - economic evaluation and alternatives for improvement. Research Bulletin No. 10. International Crops Research Institute for the Semi-Arid Tropics (ICRISAT), Patancheru, India.

Wani, S.P., Pathak, P., Sreedevi, T.K., Singh, H.P. and Singh, P. (2003a) Efficient management of rainwater for increased crop productivity and groundwater recharge in Asia. In: Kijne, W., Barker, R. and Molden, D. (eds) Water Productivity in Agriculture: Limits and Opportunities for Improvement. CAB International, Wallingford, UK, pp. 199-215.

Wani, S.P., Singh, H.P., Sreedevi, T.K., Pathak, P., Rego, T.J., Shiferaw, B. and lyer, S.R. (2003b) Farmerparticipatory integrated watershed management: Adarsha watershed, Kothapally, India - an innovative and upscalable approach. Case 7. In: Harwood, R.R. and Kassam, A.H. (eds) Research Towards Integrated Natural Resources Management: Examples of Research Problems, Approaches and Partnerships in Action in the CGIAR. Interim Science Council and Centre Directors Committee on Integrated Natural Resources Management, Consultative Group on International Agricultural Research (CGIAR), Washington, DC, USA; and Food and Agriculture Organization of the United Nations (FAO), Rome, Italy, pp. 123-147. 